\title{
INFLUENCE OF THE RIVER SHINANO ON FORAMINIFERA AND SEDIMENT GRAIN SIZE DISTRIBUTIONS
}

\author{
$\operatorname{AUTHOR}(\mathrm{S}):$ \\ Uchio, Takayasu; Uchio, Takayasu
}

CITATION:

Uchio, Takayasu ...[et al]. INFLUENCE OF THE RIVER SHINANO ON FORAMINIFERA AND SEDIMENT GRAIN SIZE DISTRIBUTIONS. PUBLICATIONS OF THE SETO MARINE

BIOLOGICAL LABORATORY 1962, 10(2): 363-392

\section{ISSUE DATE:}

1962-12-31

URL:

http://hdl.handle.net/2433/175306

RIGHT: 


\title{
INFLUENCE OF THE RIVER SHINANO ON FORAMINIFERA AND SEDIMENT GRAIN SIZE DISTRIBUTIONS ${ }^{1)}$
}

\author{
TAKAYASU UCHIO \\ Petroleum Engineering Institute, University of Tokyo, Tokyo
}

With Plate XVIII, 14 Text-figures and 3 Tables

\section{Introduction}

The River Shinano is the longest river in Japan. Its location and the area where the bottom sediments for this study were collected are shown in Figure 1. Coastal subsidence and beach erosion around the estuary of the River Shinano have been discussed recently. In 1958, more than 150 sediment samples, each about $1.2-2 \mathrm{~km}$ apart, were collected in the area shollower than $65 \mathrm{~m}$, using a simple pipe dredge, by members of the Hydrographic Office of Japan. Grain-size analyses of these samples were made by Mr. T. SATO (1960), who has the most extensive data of sediment analyses around the Japanese coast. I have analyzed 136 samples (see Figure 2) for a quantitative analysis of the Foraminifera. The river influence is clearly recognizable in the distribution of the Foraminifera and grain size in these sediment samples.

Before going into a detailed description of the foraminiferal analysis, it should be pointed out that there are many papers on brackish water foraminiferal assemblages in bays, lagoons, sounds, estuaries, etc., but few on those in the open ocean. Therefore, brackish water foraminiferal assemblages from the open ocean are of interest both from the ecological and oceanographical point of view.

It gives me a great pleasure to dedicate this paper to Professor Francis P. SHEPARD in thanks for the advice and help he gave me when attending the Scripps Institution of Oceanography, La Jolla, California. I wish to express my sincere thanks to Mr. Takahiro SATo of the Hydrographic Office of Japan, who gave me these sediment samples for study of the Foraminifera and whose data on their grain-size analysis have been of great use in my work; to Prof. Fred B

1) Presented at the Tenth Pacific Science Congress of the Pacific Science Association, held at the University of Hawaii, Honolulu, Hawaii, U.S.A., 21 August to 6 September, 1961, and sponsored by the National Academy of Sciences, Bernice Pauahi Biship Museum, and the University of Hawaii. An abbreviated form of this paper appeared in the "Shepard Commemorative Volume: Papers in Marine Geology" published by MacMillan Publishing Co., New York, 1962.

Publ, Seto Mar. Biol. Lab., X (2), 1962. (Article 18) 
Phleger and Miss Frances L. Parker, Scripps Institution of Oceanography, University of California, for reading this manuscript; to Prof. Yoshiyuki Matsue, Fisheries Department, University of Tokyo, and Dr. Toshimasa Shimomura, Japan Sea Regional Fisheries Research Laboratory, who gave me advice on the

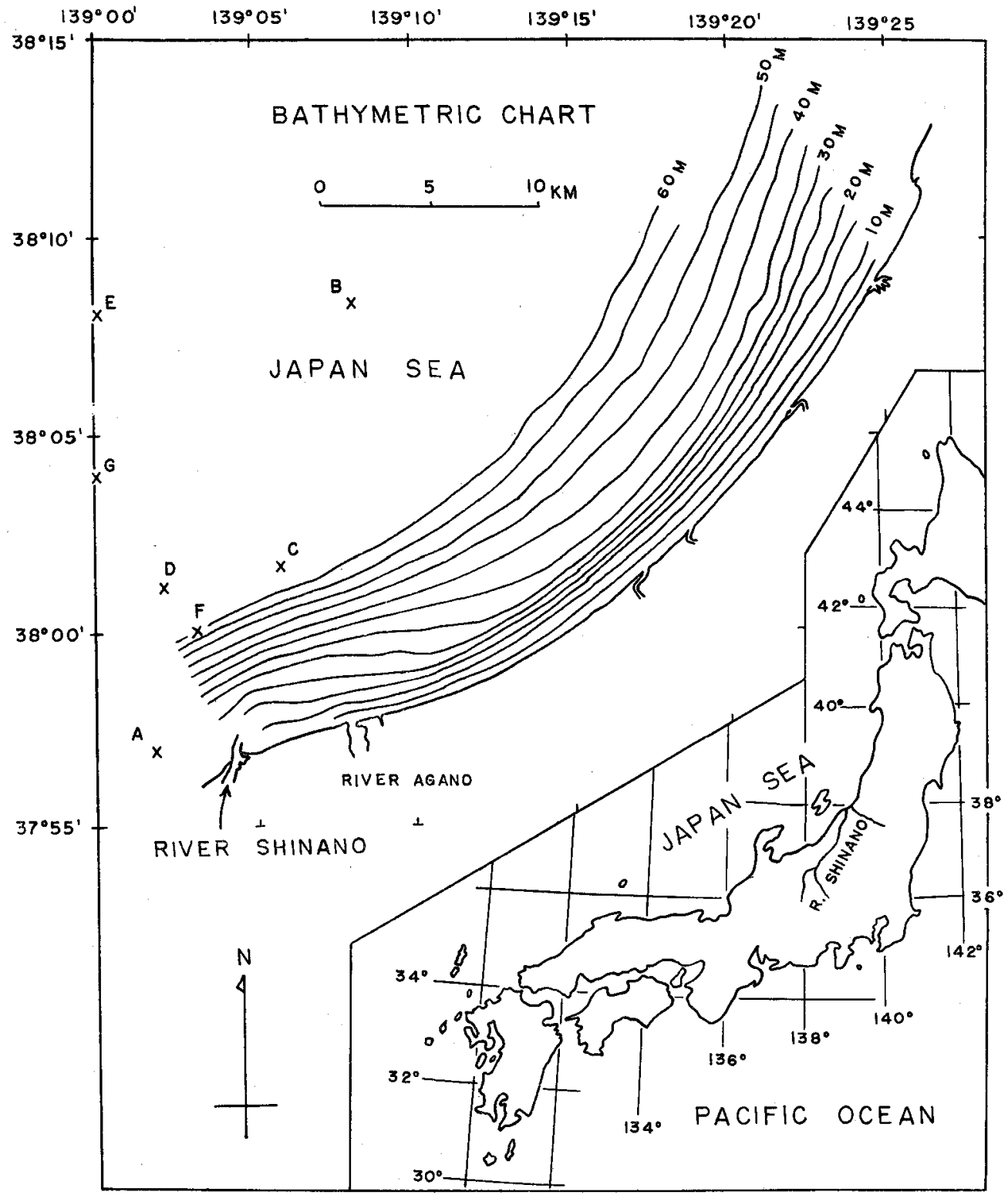

Figure 1. Bathymetric chart of the seas studied. Locations of stations $A-G$, at which chlorinity and temperature measurements were made, are shown. 
hydrographic information. Niigata Prefectural Fisheries Experimental Station furnished me with temperature and chlorinity data of sea water at Station F. Prof. Tomofusa Mitsuchi of my institution and Prof. Takasi TokiokA, Seto Marine Biological Laboratory of Kyoto University have given constant encouragement to my study of Recent Foraminifera.

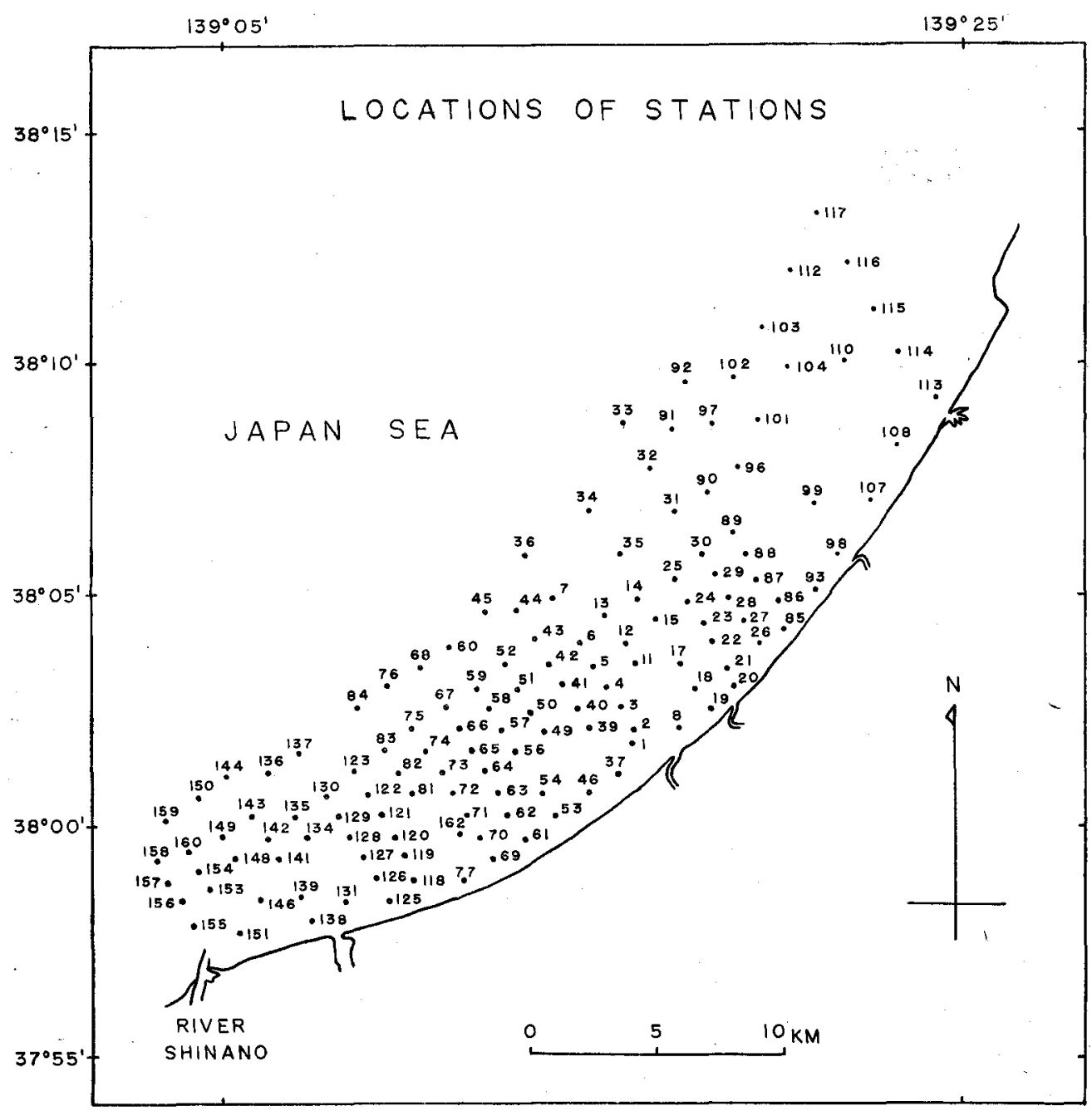

Figure 2. Locations of stations, at which sediment samples studied were taken.

\section{Hydrography}

The Foraminifera assemblages discussed here are not biocoenoses but thanatocoenoses and for this reason there may be no direct relationship between these 
assemblages and the hydrographic phenomena. However, the thanatocoenoses may well be related to the average oceanographic conditions pertaining during the past few hundred or thousand years. For this reason, I shall give a general picture of the oceanographic conditions in the area studied and that surrounding it.

It is well known that a coastal branch of the warm Tsushima Current flows along the coast of Honshu, on the Japan Sea side, in northeasterly direction, and that in the offshore region below the Tsushima Current (ca. 200-250 $\mathrm{m}$ in depth) there is the cold Liman Current which is, in turn, underlain by the characteristic water mass of the Japan Sea (Intermediate, Deep and Bottom waters). Only very few oceanographic data are available for the area concerned, since this area is a coastal region and is not important for fisheries or for meteorological observations. This area is covered by the Tsushima Current and, according to Shimomura and Miyata (1957, p. 32), the depth of the seasonal thermocline is $20 \mathrm{~m}$ off the River Shinano and $25 \mathrm{~m}$ off the Noto Peninsula. The surface water (shallower than $25 \mathrm{~m}$, particularly above $10 \mathrm{~m}$ ) of the Tsushima Current is influenced by river run-off and rain fall, but particularly in spring and summer

Table $1 \mathrm{~A}$. Some summer temperatures and chlorinities at Stations A, B, C, D, E and H (after Akagawa, 1952, Hydrographic Office of Japan, 1955 and Niigata Prefectural Fisheries Experimental Station, 1954).

\begin{tabular}{|c|c|c|c|c|c|c|c|c|c|c|c|c|}
\hline \multirow{2}{*}{\multicolumn{2}{|c|}{ Station }} & \multicolumn{6}{|c|}{ Temperature $\left({ }^{\circ} \mathrm{C}\right)$} & \multicolumn{5}{|c|}{ Chlorinity $(\%)$} \\
\hline & & A & B & $\mathrm{C}$ & $\mathrm{D}$ & $\mathrm{E}$ & $\mathbf{H}$ & B & C & $\mathrm{D}$ & $\mathrm{E}$ & $\mathrm{H}$ \\
\hline \multirow{6}{*}{$\begin{array}{l}\text { Depth } \\
\text { in } \\
\text { water } \\
\text { column } \\
\text { (m) }\end{array}$} & 0 & 20.4 & 26.9 & 27.0 & 26.6 & 24.9 & 25.6 & 18.00 & 17.81 & 18.56 & 17.44 & 18.58 \\
\hline & 10 & 19.9 & 26.37 & 26.57 & 26.29 & 24.72 & 25.73 & 18.56 & 18.11 & 18.62 & 17.84 & 18.56 \\
\hline & 25 & & 25.40 & 23.43 & 23.74 & 20.98 & 24.26 & 18.92 & 18.82 & 18.77 & 18.86 & 18.67 \\
\hline & 50 & & 20.74 & 20.25 & 20.08 & 19.06 & 21.43 & 18.99 & 18.92 & 18.88 & 18.95 & 18.90 \\
\hline & 75 & & 16.87 & & 15.91 & 17.54 & 19.55 & & & 18.98 & 18.32 & 18.94 \\
\hline & 100 & & & & & 13.37 & & & & & 19.02 & \\
\hline \multirow{2}{*}{\multicolumn{2}{|c|}{ Date }} & 1951 & 1951 & 1951 & 1951 & 1952 & 1950 & 1951 & 1951 & 1951 & 1952 & 1950 \\
\hline & & Jury & Aug. & Aug. & Aug. & Aug. & & Aug. & Aug. & Aug. & Aug. & sept. \\
\hline
\end{tabular}

Table 1B. Some winter temperatures and chlorinities at Station G (after Niigata Prefectural Fisheries Experimental Station, 1954).

\begin{tabular}{c|ccccc|ccc}
\hline \hline Depth (m) & \multicolumn{5}{c|}{ Temperature $\left({ }^{\circ} \mathrm{C}\right)$} & \multicolumn{3}{|c}{ Chlorinity $(\%)$} \\
\hline 0 & 20.4 & 15.6 & 14.3 & 9.0 & 9.4 & 17.92 & 18.75 & 18.33 \\
10 & 20.32 & 15.73 & 14.41 & 9.2 & 9.3 & 17.14 & 18.81 & 18.51 \\
25 & 20.50 & 15.87 & 14.14 & 9.2 & 9.13 & 18.10 & 18.90 & 18.33 \\
50 & 19.73 & 15.41 & 13.81 & 9.5 & 9.21 & 18.87 & 18.76 & 18.53 \\
100 & 16.48 & 15.12 & 13.10 & 9.4 & 9.47 & 19.15 & 18.58 & 18.50 \\
& 1953 & 1953 & 1953 & 1954 & 1954 & 1953 & 1953 & 1953 \\
Date & Oct. & Nov. & Dec. & Feb. & Mar. & Oct. & Nov. & Dec. \\
\hline
\end{tabular}


Table 2A. Monthly average temperatures $\left({ }^{\circ} \mathrm{C}\right)$ of sea water at Station $\mathrm{F}\left(38^{\circ} 00^{\prime} \mathrm{N}\right.$. Lat., $139^{\circ} 83^{\prime}$ E. Long.) during April 1953-Octover 1961 . The numbers in parentheses under the temperatures indicate numbers of mesurements (Calculated from the data measured by Niigata Prefectural Fisheries Experimental Station).

\begin{tabular}{c|cccccccccccc}
\hline Depth (m) & Feb. & Mar. & April & May & June & July & Aug. & Sept. & Oct. & Nov. & Dec. \\
\hline \multirow{2}{*}{0} & 9.43 & 9.23 & 10.71 & 14.20 & 17.86 & 22.86 & 26.20 & 25.83 & 22.11 & 17.76 & 15.00 \\
& $(3)$ & $(6)$ & $(8)$ & $(9)$ & $(9)$ & $(5)$ & $(2)$ & $(8)$ & $(8)$ & $(6)$ & $(2)$ \\
10 & 9.91 & 9.50 & 10.65 & 12.87 & 16.28 & 20.12 & 25.27 & 25.14 & 21.94 & 18.16 & 14.95 \\
& $(3)$ & $(6)$ & $(8)$ & $(9)$ & $(9)$ & $(5)$ & $(2)$ & $(7)$ & $(8)$ & $(6)$ & $(2)$ \\
20 & & & 10.10 & 12.53 & 16.83 & & & 26.75 & 24.24 & & \\
& & & $(1)$ & $(1)$ & $(1)$ & & & $(1)$ & $(1)$ & & \\
25 & 10.10 & 9.64 & 10.11 & 11.95 & 14.99 & 19.23 & 22.92 & 24.25 & 21.57 & 18.26 & 12.01 \\
& $(3)$ & $(6)$ & $(7)$ & $(8)$ & $(8)$ & $(5)$ & $(2)$ & $(7)$ & $(7)$ & $(6)$ & $(2)$ \\
30 & & & 10.00 & 11.82 & 16.67 & & & 26.14 & 23.48 & & \\
& & & $(1)$ & $(1)$ & $(1)$ & & & $(1)$ & $(1)$ & & \\
50 & 9.79 & 9.71 & 9.73 & 11.12 & 13.90 & 17.28 & 19.48 & 21.94 & 20.25 & 17.89 & 14.87 \\
& $(3)$ & $(6)$ & $(8)$ & $(8)$ & $(9)$ & $(5)$ & $(2)$ & $(8)$ & $(8)$ & $(6)$ & $(2)$ \\
75 & 10.24 & 9.53 & 9.96 & 11.43 & 12.70 & & 17.99 & 19.02 & 18.16 & 18.11 & $(4)$ \\
100 & $(1)$ & $(1)$ & $(4)$ & $(3)$ & $(3)$ & & $(1)$ & $(3)$ & $(4)$ & $(4)$ & \\
& 9.32 & & 10.32 & 10.44 & 11.51 & & & & 15.90 & & \\
& $(1)$ & & $(1)$ & $(1)$ & $(2)$ & & & & $(1)$ & & \\
\hline
\end{tabular}

Table 2B. Monthly average chlorinities $(\%)$ of sea water at Station F $\left(38^{\circ} 00^{\prime} \mathrm{N}\right.$. Lat., $139^{\circ} 83^{\prime}$ E. Long.) during April 1953-Octover 1961. The numbers in parentheses under the chlorinities indicate numbers of measurements (Calculated from the data measured by Niigata Prefectual Fisheries Experimental Station).

\begin{tabular}{c|cccccccccccc}
\hline Depth (m) & Feb. & Mar. & April & May & June & July & Aug. & Sept. & Oct. & Nov. & Dec. \\
\hline \multirow{2}{*}{0} & 18.47 & 18.12 & 18.33 & 17.27 & 18.24 & 16.85 & 18.64 & 17.88 & 18.11 & 18.42 & 18.11 \\
& $(1)$ & $(4)$ & $(7)$ & $(8)$ & $(8)$ & $(5)$ & $(1)$ & $(7)$ & $(7)$ & $(6)$ & $(2)$ \\
10 & 18.60 & 18.68 & 18.66 & 18.31 & 18.65 & 18.59 & 18.54 & 18.21 & 18.40 & 18.56 & 18.44 \\
& $(2)$ & $(4)$ & $(8)$ & $(8)$ & $(9)$ & $(5)$ & $(1)$ & $(6)$ & $(7)$ & $(5)$ & $(2)$ \\
20 & & & 18.78 & 17.98 & 18.99 & & & 18.56 & 18.57 & & \\
& & & $(1)$ & $(1)$ & $(1)$ & & & $(1)$ & $(1)$ & & \\
25 & 18.70 & 18.83 & 18.85 & 18.81 & 18.97 & 18.97 & 18.79 & 18.68 & 18.41 & 18.54 & 18.49 \\
& $(2)$ & $(4)$ & $(7)$ & $(7)$ & $(7)$ & $(5)$ & $(1)$ & $(6)$ & $(6)$ & $(6)$ & $(2)$ \\
30 & & & 18.84 & 18.77 & 19.00 & & & 18.56 & 18.75 & & \\
& & & $(1)$ & $(1)$ & $(1)$ & & & $(1)$ & $(1)$ & & \\
50 & 18.58 & 18.89 & 18.99 & 18.86 & 19.03 & 19.29 & 19.18 & 18.98 & 18.80 & 18.65 & 18.40 \\
& $(2)$ & $(4)$ & $(8)$ & $(8)$ & $(9)$ & $(5)$ & $(1)$ & $(7)$ & $(7)$ & $(6)$ & $(2)$ \\
75 & 18.57 & 18.88 & 18.95 & 18.86 & 18.96 & & 19.12 & 19.11 & 18.63 & 18.79 & $(12)$ \\
& $(1)$ & $(1)$ & $(4)$ & $(2)$ & $(3)$ & & $(1)$ & $(2)$ & $(4)$ & $(4)$ & \\
100 & 18.52 & & & & 18.94 & & & & 19.09 & & \\
& $(1)$ & & & & $(3)$ & & & & $(1)$ & & \\
\hline
\end{tabular}

by the low saline water of the Eastern China Sea flowing into the Japan Sea through the Tsushima Channel. Thus, the chlorinity of the surface water is low and that of the water below $25 \mathrm{~m}$ level of the Tsushima Current is the highest. Some temperature and chlorinity data at eight stations $\mathrm{A}-\mathrm{H}$ in this area are given below (Tables $1 \mathrm{~A}, \mathrm{~B}, 2 \mathrm{~A}, \mathrm{~B}$ ) for reference. Stations $\mathrm{A}-\mathrm{G}$ are shown on Figure 
1. The location of Station $\mathrm{H}$ is at $37^{\circ} 53.8^{\prime} \mathrm{N}$. Lat., $138^{\circ} 50^{\prime} \mathrm{E}$. Long. and it is about $23 \mathrm{~km}$ southwest of Station G. It is unfortunate that these 8 stations (A-H) are not influenced by the River Shinano. According to Dr. Shimomura (personal communication, Nov. 1, 1961), the thickness of the fresh water-layer of the Shinano is $c a .3 \mathrm{~m}$ at the estuary and $c a .20-40 \mathrm{~cm}$ at points about $1-2$ nautical miles from the estuary. The chlorosity of the water above and below the $3 \mathrm{~m}$ boundary is less than $2 \mathrm{~g} / \mathrm{L}$ and more than $10 \mathrm{~g} / \mathrm{L}$ respectively and there is no transitional zone between the two. The volume transport of the River Shinano is $c a .300-500 \mathrm{~m}^{3} / \mathrm{sec}$.

\section{Submarine Topography}

The continental shelf off the coast of the northern part of Niigata Prefecture is very broad, being about $40-50 \mathrm{~km}$ wide. The depth of the'shelf edge is about $150-160 \mathrm{~m}$. The area surveyed in this study includes only the inner part of the shelf (see Figure 1). Contours were drawn at 5-meter intervals. These contours show that (1) the surface of the sea floor is smooth indicating that the area is presently depositional (i. e. is covered by Recent sediments ; coarse sediments are known to be present farther offshore, indicating the presence of premodern sediments) and that (2) there is no subareal delta although there is a submarine delta-like feature at the mouth of the Shinano. The contours are about equally spaced in the northeastern part of the area, while the slope of the sea floor near the mouth of the River Shinano is stecper at the outer part. In the central part of the area, the slope of the floor is much steeper in the inner part than in the outer. This submarine topography is certainly due to the pouring of detrital sediments into the sea by the River Shinano and to the transportation of these sediments by the northeasterly flow of the Tsushima Current. The contours also show (3) that there is no influence on the submarine topography by the River Agano, though we can notice some influence by this river on the sediment grain size and Foraminifera distributions.

\section{Grain-Size Distribution}

Grain-size analyses of the sediments were made by Mr. T. Sato (1960). His results $\left(\mathrm{Md}_{\phi}\right.$ distribution) are given here (Figure 3 ) for reference. The distribution of the $\mathrm{Md}_{\phi}$ contours of the sediments is very complicated off the mouth of the rivers Shinano and Agano, but is simple and nearly parallel to the shoreline in the northeastern part of the region where no strong river influence is recognized. Coarse sediments are distributed farther offshore near the mouth of the Shinano than they are off the rest of the area. It is apparent that the River Shinano has a great influence on the distribution of the sediment grain size and that the River Agano has the same influence, though to a lesser extent. Sato 
(op. cit., p. 715, fig. 4) found a remarkable change in $\mathrm{Md}_{\phi}$ value at depths of $c a$. $10 \mathrm{~m}$ and $35 \mathrm{~m}$ ( $\mathrm{Md}_{\phi}$ value being $c a .2 .5$ between $10 \mathrm{~m}$ and $35 \mathrm{~m}$ ) and he considered the depth of $10 \mathrm{~m}$ to be the base of breaker action and the $35 \mathrm{~m}$ depth to be the so-called "wave-base" as well as the inner margin of the "mud belt".

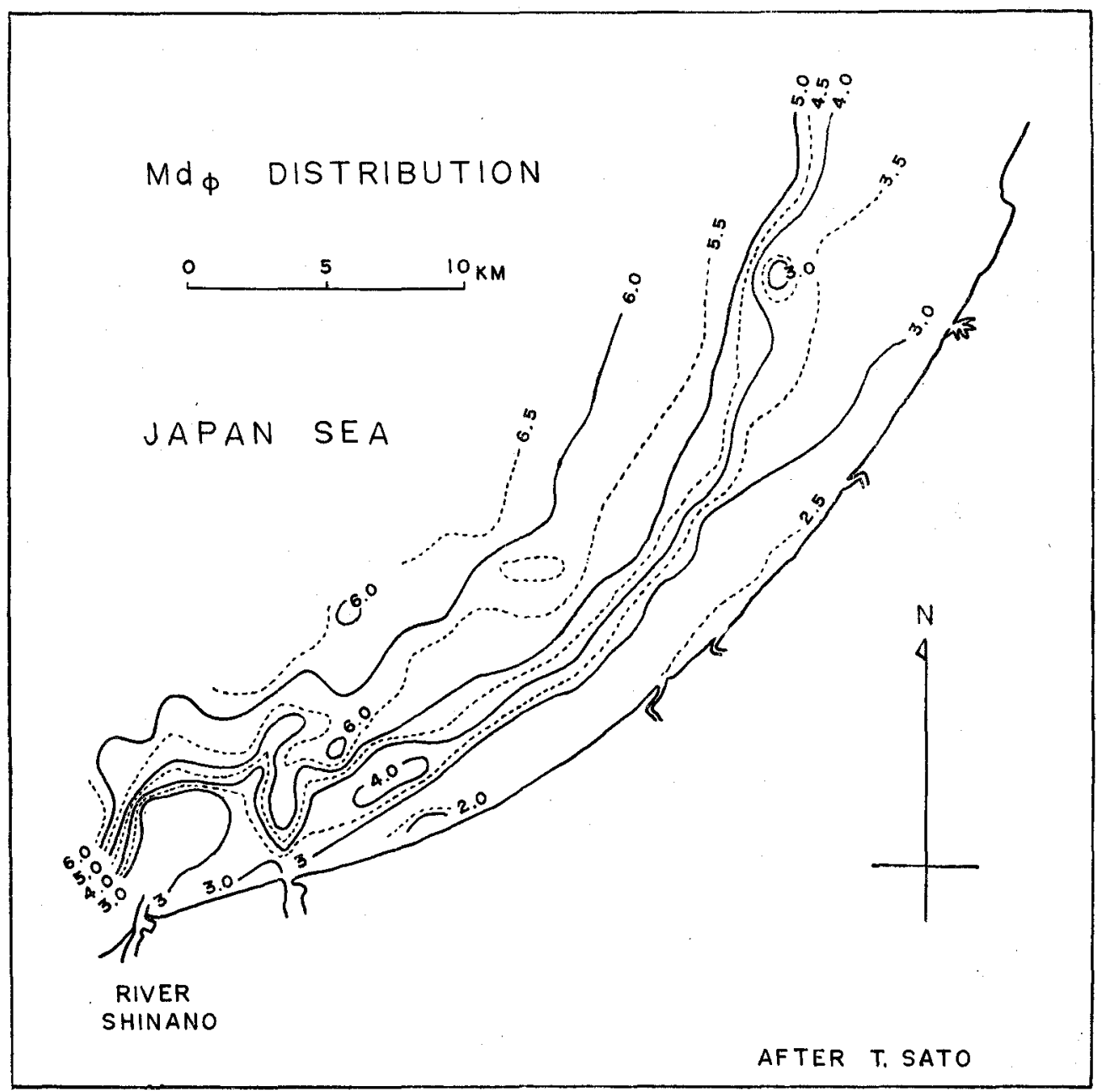

Figure 3. Distribution of grain size of sediments $\left(\mathrm{Md}_{\phi}\right)$ (after T. SATO, 1960).

\section{Foraminifera Distribution}

Foraminifera assemblages mentioned here are thanatocoenoses but most of the foraminiferal tests have a fresh appearence, with the exception of a few specimens of Elphidium, Ammonia, Siphogenerina, etc. Therefore, any conclusions 
obtained from this study may be modified when a detailed study of biocoenoses of Foraminifera are made in the future. It is believed that the major features of the distributiona are essentially correct. A total of 102 species and varieties have been found in the area studied, of which only two are planktonic. Frequency distributions of major constituents of the benthonic species are shown in Table 3.

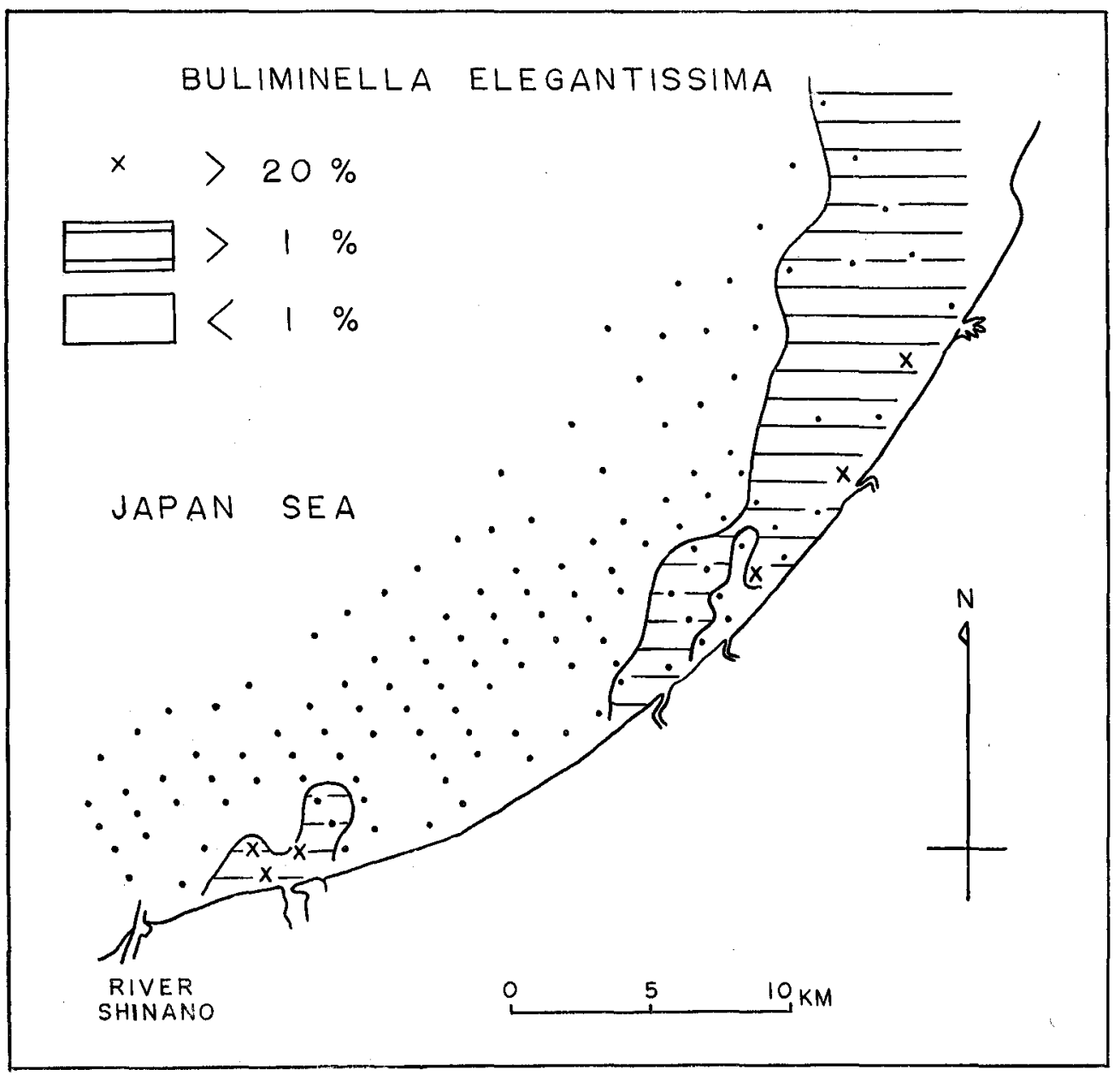

Figure 4. Distribution of Buliminella elegantissima (D'ORBIGNY).

The planktonic species are Globigerina sp. (young form) and Globigerinoides ruber (D'ORBIGNY), their occurrences are scattered and extreamely rare, and they are not listed in Table 3. By the same reason many benthonic species are not listed in Table 3. However, two very interesting species, Pseudobulimina simaensis (MakiYama \& NAKagawa) and Asterigerinata sp. cf. A. pacifica Uchio, are 
discussed later. It is to be noticed that seventeen species found in this area are also known from shallow marine sediments off the coast of Noboribetsu, southwestern Hokkaido, which is influenced by the cold Oyashio Current (Uchio, 1959, p. 300, Table 2). They are Elphidium clavatum, Buliminella elegantissima, Eggerella

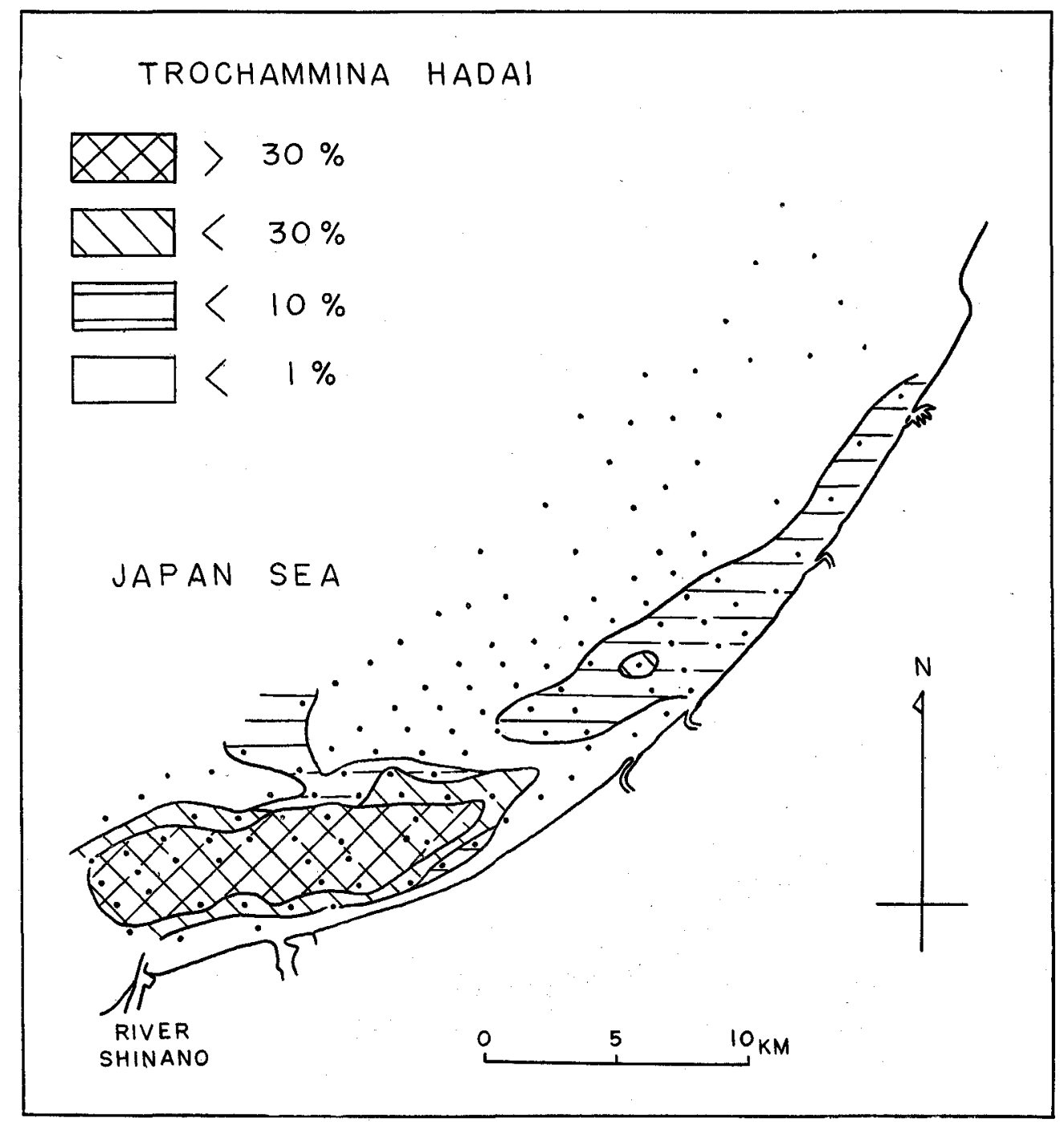

Figure 5. Distribution of Trochammina hadai UcHIo,n. sp.

advena, E. scabra, Pseudononion japonicum, Buccella frigida, Textularia earlandi, Trochammina cf. pacifica (or charlottensis), Nonionella stella, Epistominella tamana, Ammodiscus cf. minutissimum, Nonion manpukujiense, Trochammina cf. squamata, 
Alveolophragmium crassimargo, Reophax scorpiurus, Asterigerinata cf. pacifica and Ammonia japonica. Of these, the presence of true cold water species as Elphidium clavatum is noteworthy. Eggerella advena and Buliminella elegantissima seem to prefer a cold shallow water environment, but they, particularly the latter species, are also reported from warm shallow water environment. Elphidium clavatum in

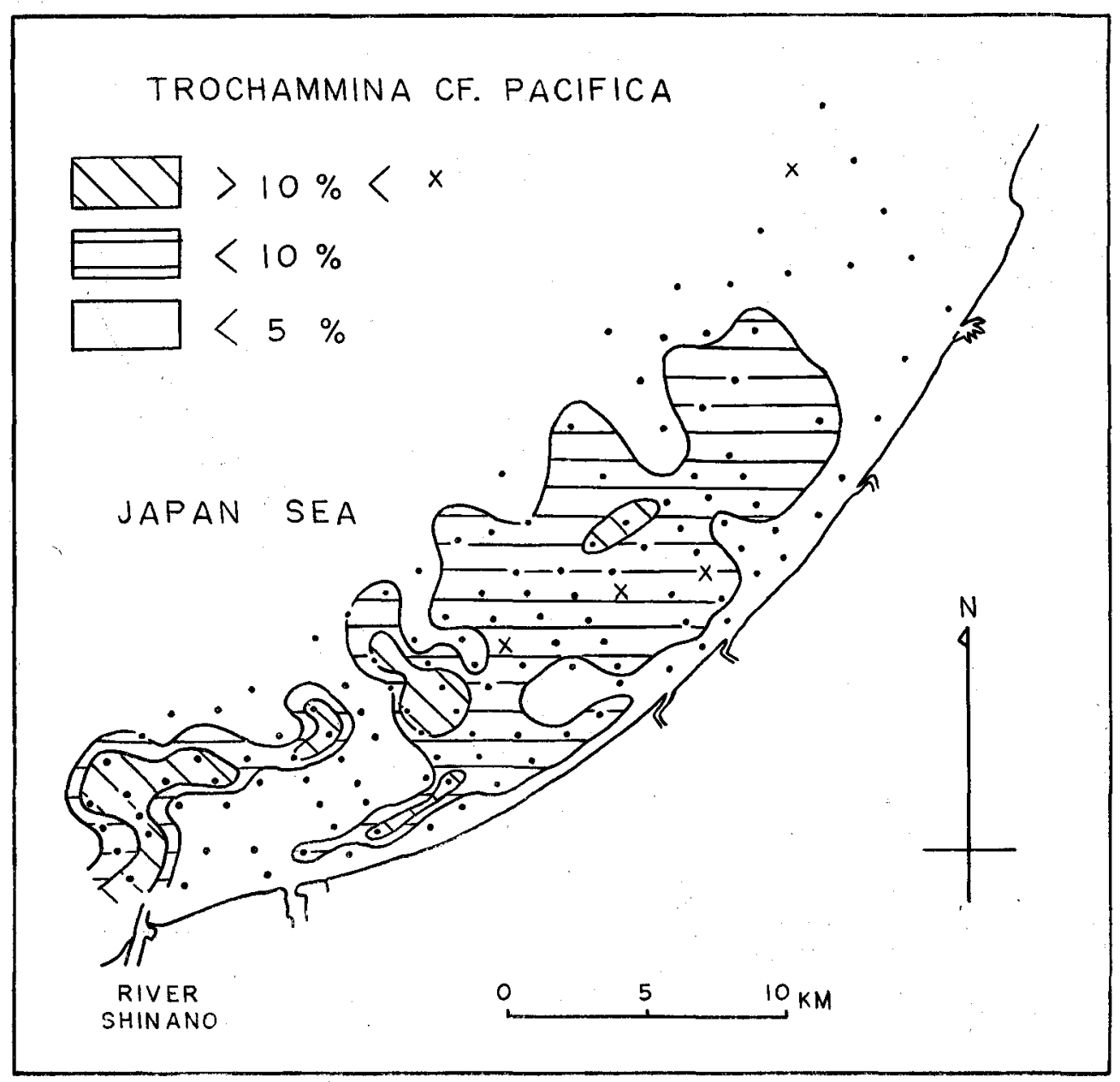

Figure 6. Distribution of Trochammina cf. T. pacifica Cushman.

this area may be a relict of the Pleistocene Period, but it is more probable to think that the area off the River Shinano is close to the southern limit of the distribution of Elphidium clavatum in Japan Sea. In the following paragraphs, the distribution of important species, rare but interesting species, benthonic populations and Foraminifera facies are discussed briefly. 
Asterigerinata cf. pacifica UcHIo occurs at Station 26 (depth $9.8 \mathrm{~m}$ ) in very low frequency $(0.1 \%)$. The species was reported (Uсніо, 1959) at Stations 2 $(65 \mathrm{~m})$ and $11(70 \mathrm{~m})$ off Noboribetsu, Hokkaido (less than 1\%).

Pseudobulimina simaensis (MakiYama \& NakAgawA) occurs at Station 15 $(42 \mathrm{~m})$ in very low frequency $(0.1 \%)$. The species was originally described from

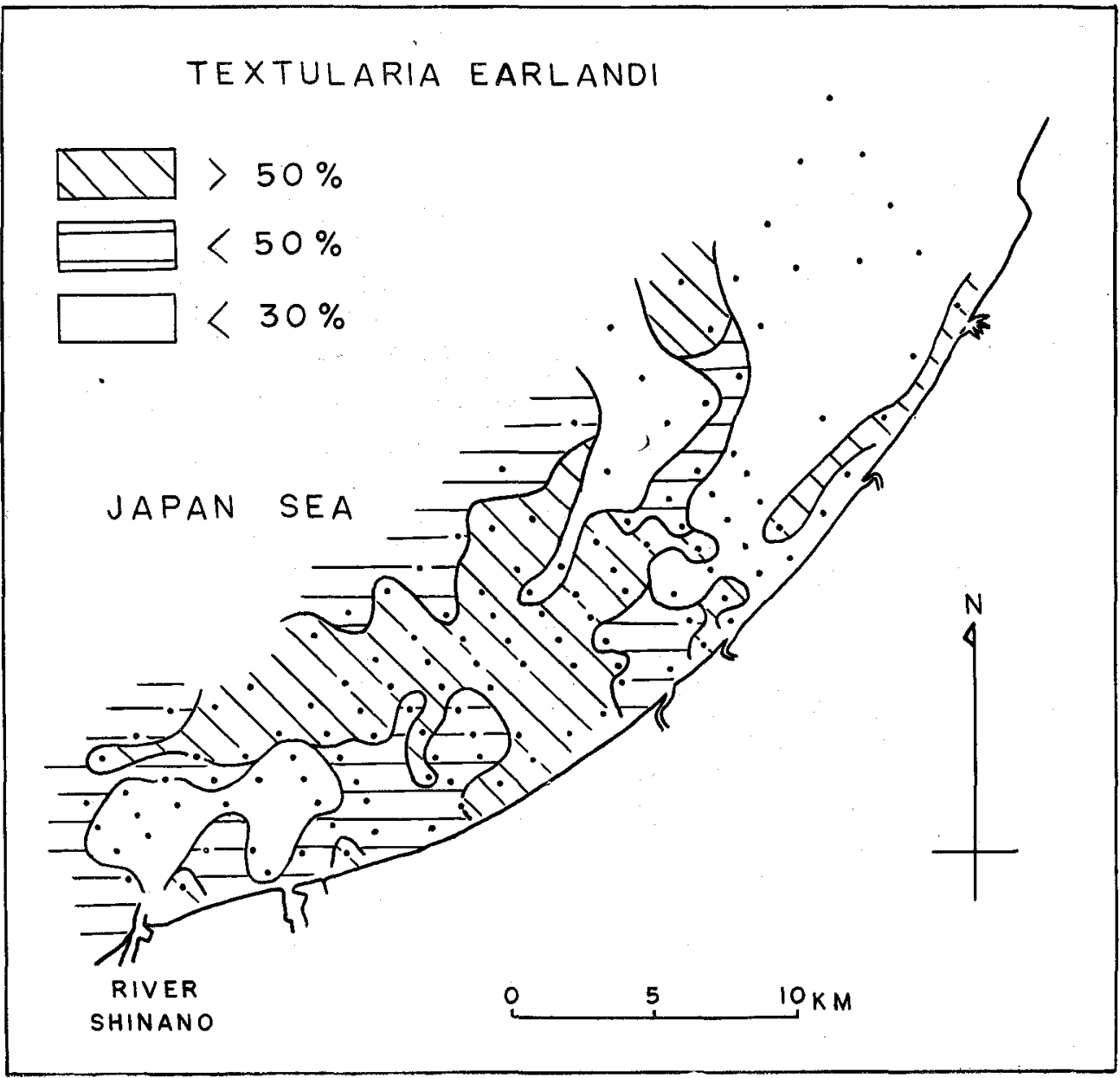

Figure 7. Distribution of Textularia earlandi PARKER.

the Pleistocene formation of Mie-ken, and I find it from the Pleistocene formations of Aichi-, Kanagawa- and Chiba-ken, and the Pliocene Setana formation in Hokkaido. Occurrences of this species in Recent sediments are known so far from only two stations off Kinkazan $(102,349 \mathrm{~m}$ ), where it is rare (AsANo, 1959, p. 13). 
Figure 4 shows the distribution of Buliminella elegantissima (D'ORBIGNY). This species is abundant in fine sand of shallow water (less than $10 \mathrm{~m}$ ) but is not abundant in very coarse sediments. It seems to prefer a sea-water environment to a brackish-water environment.

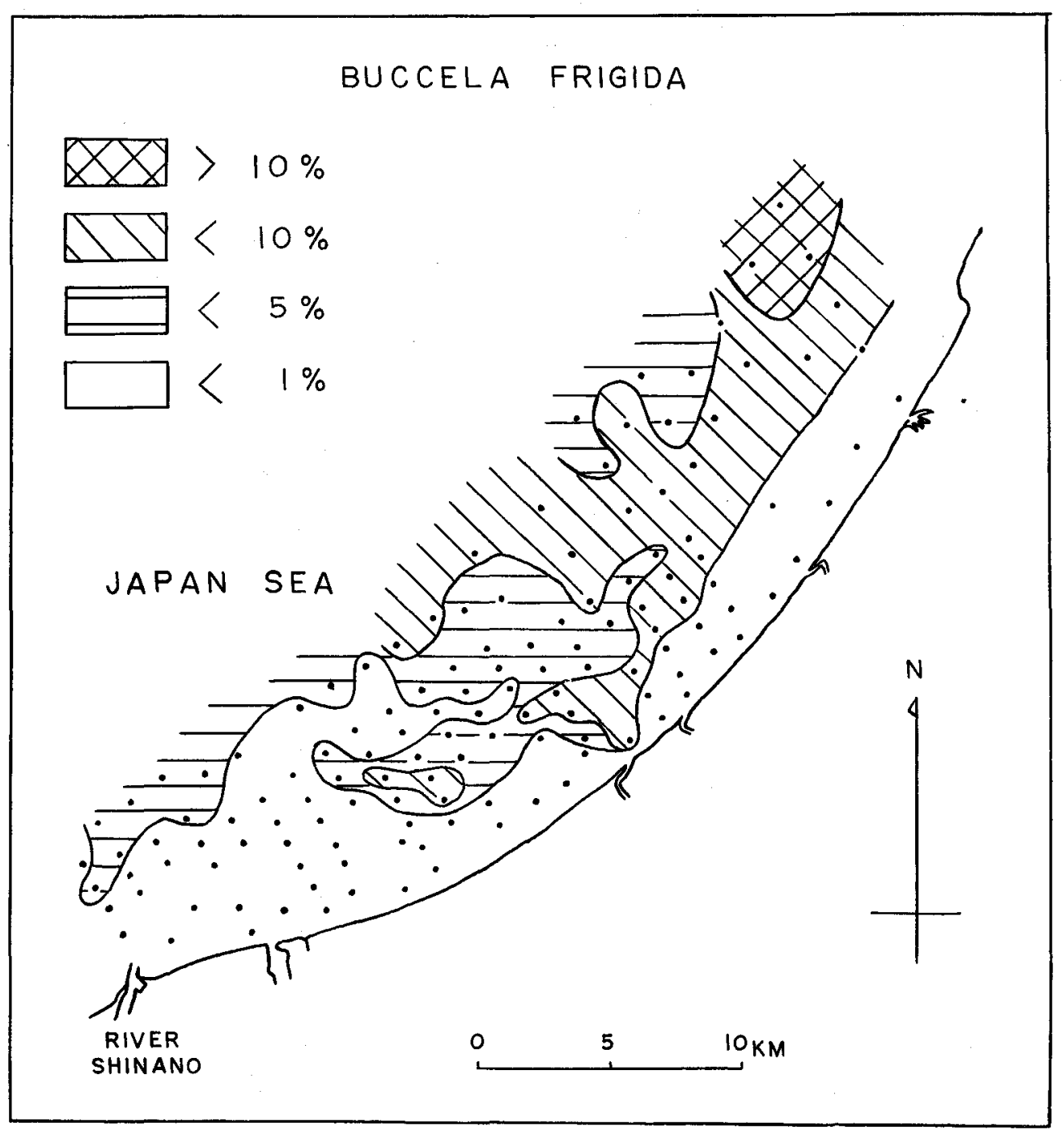

Figure 8. Distribution of Buccella frigida (CushmaN).

Figure 5 shows the distribution of Trochammina hadai UchIo, n. sp. This species is most abundant (50-80\%) off the Shinano and seems to be very sensitive to fresh water. It is reported as Trochammina globigeriniformis (PARKER \& JONES) 
from some Japanese brackish waters (HADA, 1931, 1936, 1939, 1957; MARUHASI, 1948). Those who have studied the distribution of Recent Foraminifera may remember $T$. inflata (MontaGU) which is also very characteristic of riverinfluenced areas in the United States and Europe. However, T. hadai can be easily distinguished from $T$. inflata.

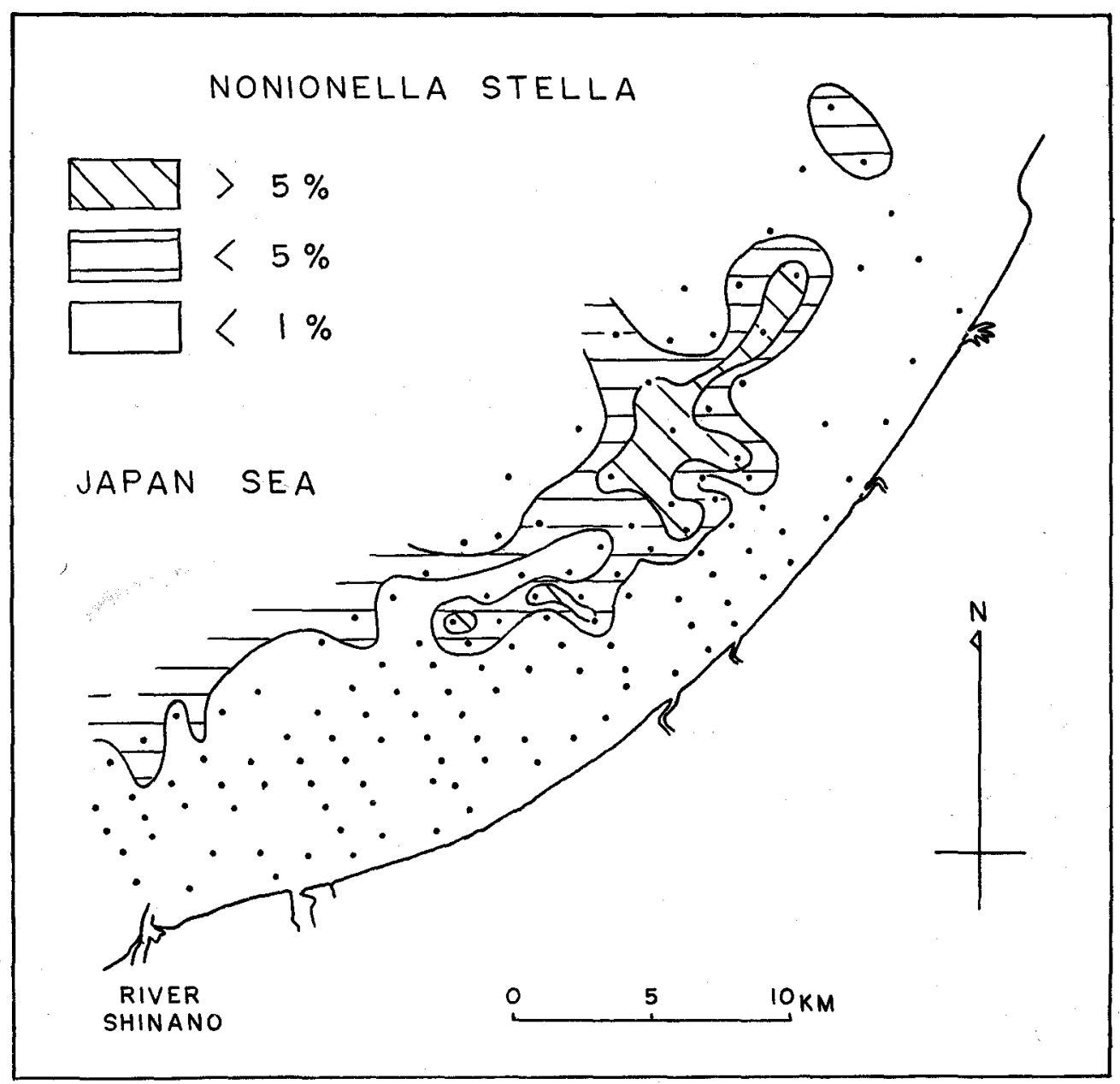

Figure 9. Distribution of Nonionella stella CUSHMAN \& MOYER.

Figure 6 shows the distribution of Trochammina sp. cf. T. pacifica Cushman. This species seems to be distributed around the margin of the distribution of $T$. hadai, though there are some exceptions. ZALESNY (1959, p. 109, text-fig. 8) finds that $T$. pacifica reaches its greatest abundance, making up $82 \%$ of the assemblage, at a point about two miles offshore in 17 fathoms of water, and the greatest 
abundance of this species lies just beyond the end of the Hyperion sewage outfall at El Segundo. With increasing distance from this point in all directions, $T$. pacifica makes up less and less of the foraminiferal assemblages. ZALESNY's findings are in an area of open-ocean conditions in Santa Monica Bay, California.

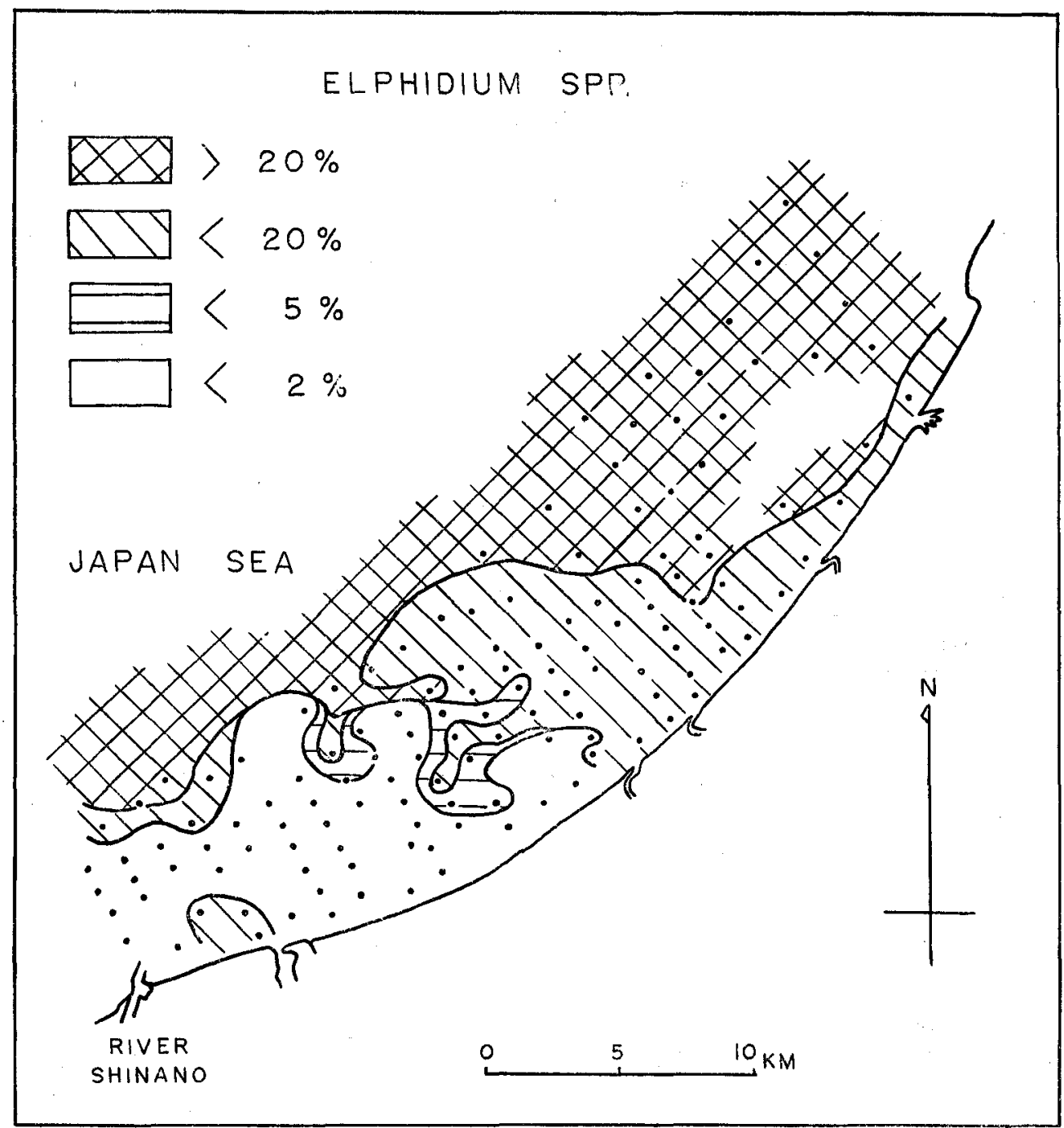

Figure 10. Distribution of Elphidium spp.

His $T$. pacifica must be different from my $T$. cf. $T$. pacifica when considered from an ecological point of view.

Figure 7 shows the distribution of Textularia earlandi PARKER. This species 
is abundant throughout the area, which can be divided into two (northeastern and southwestern) parts by the frequency distributions of the species. The species seems to prefer a shallow, marine environment that is not strongly influenced by fresh water.

Figure 8 shows the distribution of Bucella frigida (Cushman). This species,

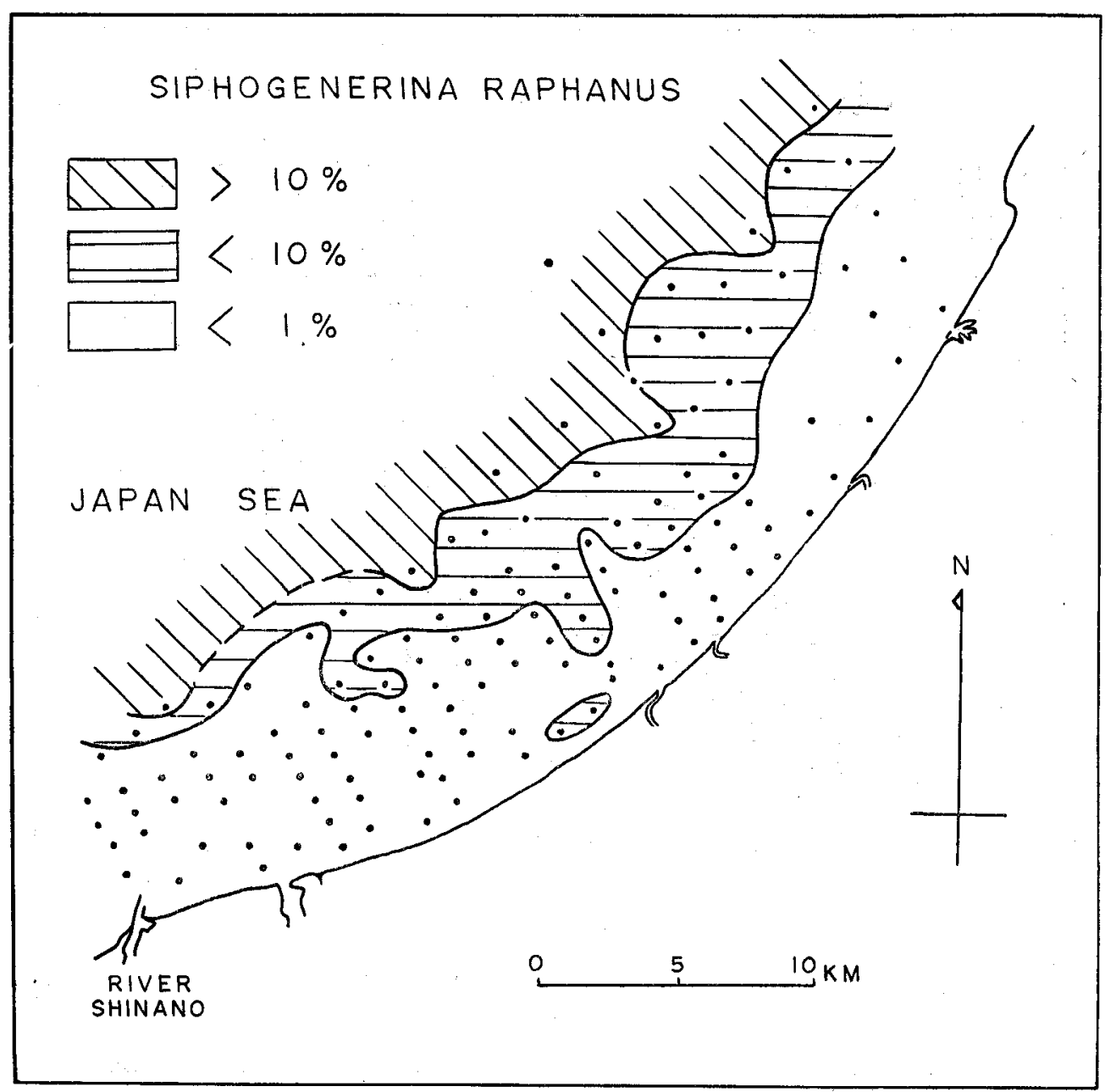

Figure 11. Distribution of Siphogenerina raphanus (PARKER \& JONEs).

like Trochammina hadai, seems to be veay sensitive to fresh water. However, contrary to Trochammina hadai, this species seems to prefer a marine environment to a brackish water environment.

Figure 9 shows that the distribution of Nonionella stella Cushman \& MoYer is rather similar to that of Buccella frigida. Nonionella stella seems to prefer a 
shallow, marine environment that is not strongly influenced by fresh water.

Figure 10 shows that Elphidium (mostly E. clavatum CusHman) is abundant in the northeastern part of the area and also in the offshore area, and seems to prefer marine water to brackish water.

Figure 11 shows that the frequency distribution of Siphogenerina raphanus

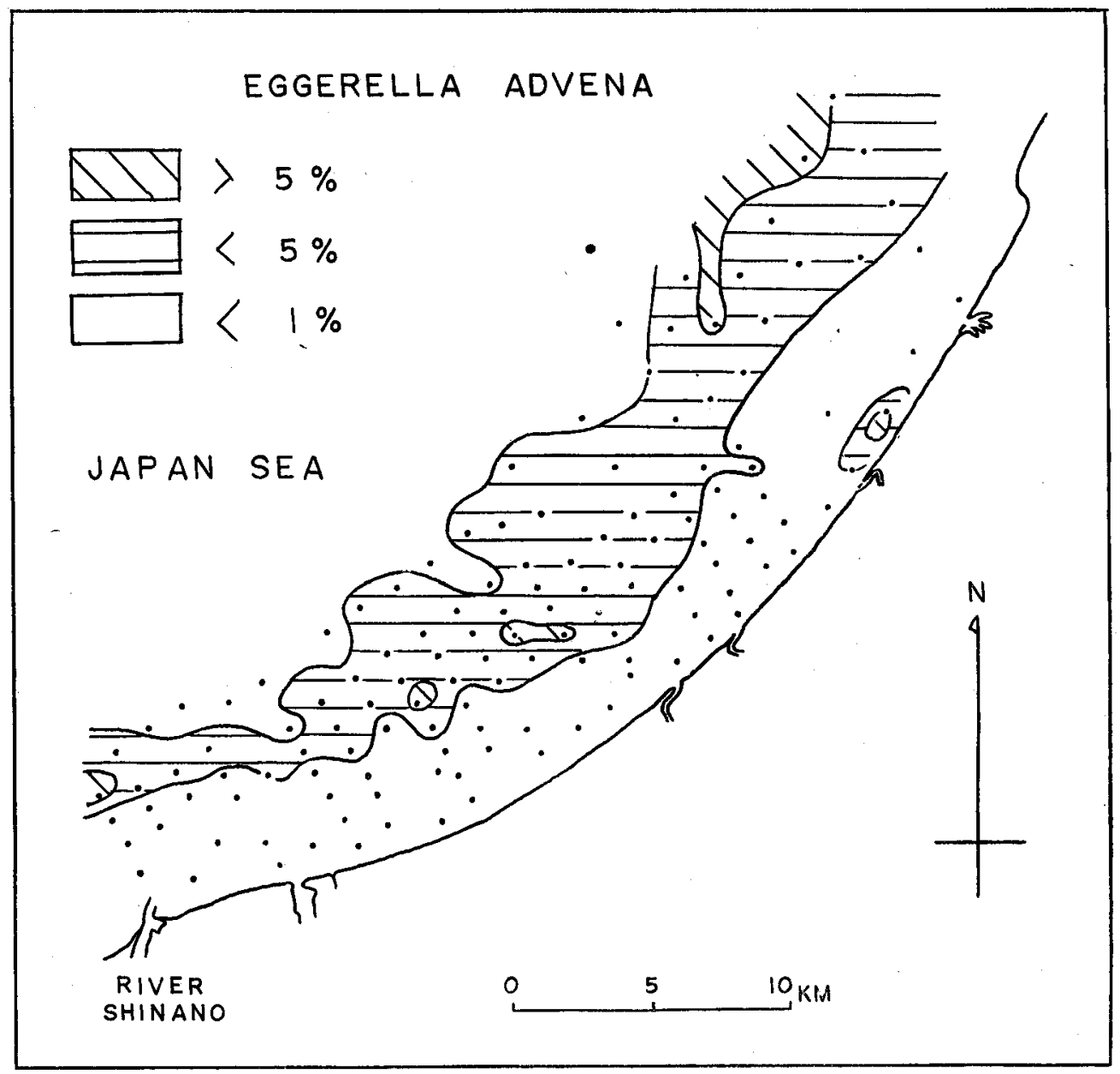

Figure 12. Distribution of Eggerella advena (CUSHMAN).

(PARKER \& Jones) is nearly parallel to the shoreline, though there seems to be a slight indication of the influence of the Shinano, and that this species becomes dominant toward offshore. This species seems to be a definitely marine species.

Figure 12 shows that the distribution of Eggerella advena (CushmaN) is similar to that of Siphogenerina raphanus, though Eggerella advena has its high 
frequency zone at depths between $c a .30$ and $60 \mathrm{~m}$ and decreases further offshore. Eggerella advena seems to prefer a shallow, marine environment that is not strongly influenced by fresh water.

Figure 13 shows that the total benthonic population is clearly affected by

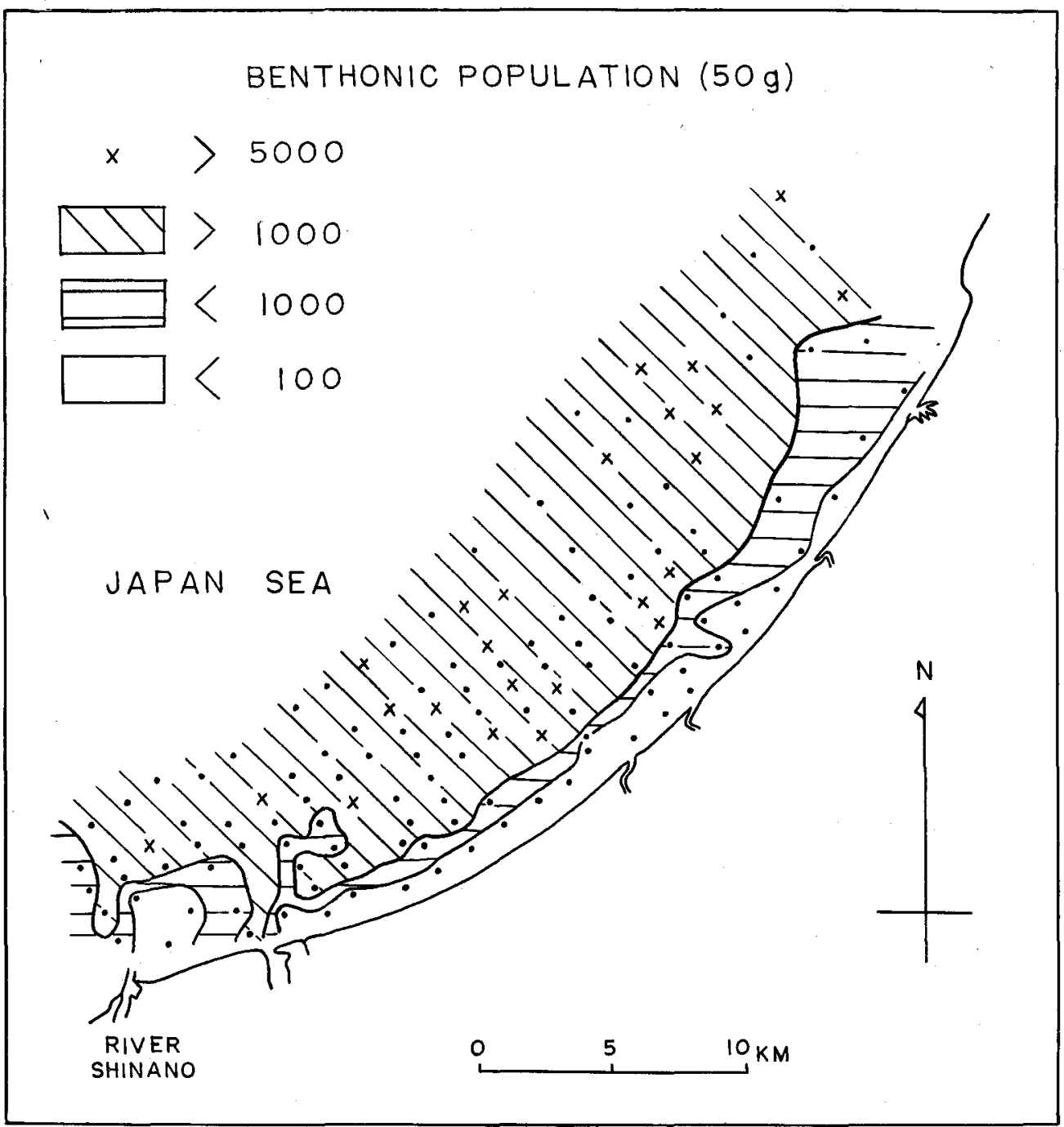

Figure 13. Distribution of benthonic foraminiferal populations (number of specimens in 50 grams of dried sediment).

$\mathrm{Md}_{\phi}$ distribution and, thus, by the River Shinano. Generally, the coarser the sediment, the smaller the Foraminifera population (compare Figure 13 with Figure 3). 
Figure 14 shows the distribution of five Foraminifera assemblages. The Trochammina Assemblage clearly shows the influence of the Shinano. Each

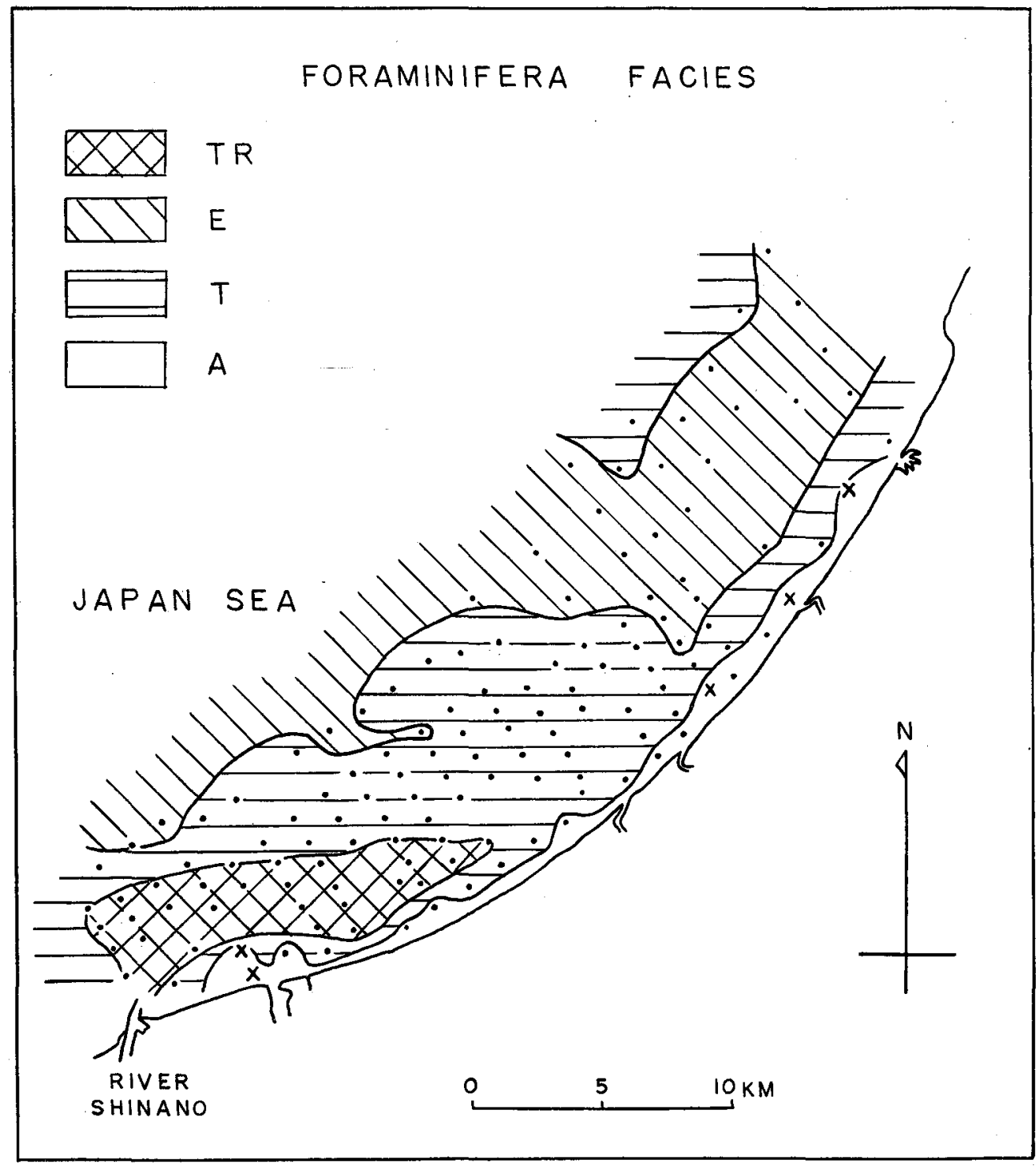

Figure 14. Distribution of foraminiferal facies showing the following assemblages : Trochammina (TR), Textularia (T), Elphidium (E), Ammonia (A), Buliminella elegantissima (D'ORBIGNY) (X).

assemblage is briefly described in the following:

(1) Ammonia Assemblage-The assemblage is characterized by the occurrence 
of high percentages of Ammonia beccarii (LINNé) var. Buliminella elegantissima is also very important and forms the highest percentages of the assemblage at five localities (see areas marked by an $X$ in Figure 14). Other species found commonly in the assemblage are Pseudononion japonicum Asano, Textularia earlandi, Elphidium spp., Rosalina bradyi (CuRHMAN), Reussella aculeata Cushman, etc. Less than ten species are found in this assemblage.

(2) Trochammina Assemblage-This assemblage is characterized by the highest frequency occurrences (usually more than 50\%, maximum 88\%) of Trochammina hadai. Other important species are Textularia earlandi and Trochammina cf. T. pacifica. Ten to thirteen species are found in this assemblage.

(3) Textularia Assemblage (I) - This is the inner Textularia assemblage and is characterized by the highest frequency occurrences (usually more than $50 \%$, maximum 93\%) of Textularia earlandi. Other important species are Trochammina cf. T. pacifica, Elphidium spp., Siphogenerina raphanus, Buccella frigida, Ammonia japonica (HADA), Pseudorotalia gaimardii (D'ORBIGNY), Nonion manpukujiense OTUKA, etc. Sometimes Bolivina cf. B. robusta BRADY, Bulimina marginata D'ORBIGNy, Nonionella stella, Pseudononion japonicum and Loxostomoides karrerianum (BRADY) are found. Ten to twenty species are found in this assemblage.

(4) Elphidium Assemblage-This assemblage is characterized by the highest frequency occurrences (20-50\%) of Elphidium spp. (mostly E. clavatum Cushman). Textularia earlandi is also abundant and usually forms higher percentages than Elphidium spp. This assemblage is distributed between the areas of the inner Textularia Assemblage (I) and the outer Textularia Assemblage (II), but is easily distinguished from them by high frequency occurrences of calcareous species, particularly Elphidium spp. and Siphogenerina raphanus, and by a greater number of species (20 to 35, average 25 species). Other important species are Ammonia japonica, Pseudorotalia gaimardii, Nonionella stella, Buccella frigida, Trochammina cf. T. pacifica, Nonion cf. N. pacificum Cushman, Epistominella tamana (Kuw ANo), Eggerella advena, Loxostomoides karrerianum, etc.

(5) Textularia Assemblage (II)-This is the outer Textularia Assemblage and is characterized by the highest frequency occurrences of Textularia earlandi. Other important species are Elphidum clavatum, Buccella frigida, Ammonia japonica and Siphogenerina raphanus. Besides, Trochammina cf. T. pacifica and Eggerella advena are also common. Thirteen to seventeen species are found in this assemblage.

The distribution of the number of genera shows the same pattern as that of the number of species.

\section{Discussion}

As can be inferred from Figures 4-14, the distributions of species, assemblages and populations of Foraminifera are not directly influenced by the depth 
of the bottom but by the River Shinano. Perhaps the physical characteristics (velocity, flow direction) of the river water and the amount of water, organic matter and detritus transported by the river are the most important factors for these peculiar distributions of Foraminifera. Temperature may be important for these distributions but the importance is obscured by the influence of the River Shinano. However, temperature influence may be recognizable in the northeastern part of the area where the boundaries of the Foraminifera assemblages are generally parallel to the shoreline.

As mentioned above, the Trochammina Assemblage clearly shows the influence of the River Shinano. T. hadai constitutes $50-80 \%$ of the assemblage, and this species is widely distributed in Japanese brackish waters in abundance. Therefore, the Trochammina Assemblage may be due to the low salinity of the sea water caused by the River Shinano. However, the salinity of the bottom water in the area is as high as that of normal sea water, because the thickness of the freshwater layer from the River Shinano is about $3 \mathrm{~m}$ at the estuary and $20-40 \mathrm{~cm}$ at 1-2 nautical miles from the estuary and the river water does not touch the sea floor. Thus, salinity is not the main factor limiting the distribution of the Trochammina Assemblage. It appears that the same is true of the distribution of Trochammina pacifica in Santa Monica Bay (ZALEsny, 1959). According to HAdA (1957, p. 48, 49), who has studied brackish-water Foraminifera of coastal lagoons and lakes of Japan, there are 15 species of Foraminifera that are adapted to brackish waters with salinities below 30\%, of which two-thirds are arenaceous forms. HADA believes that they consist of cosmopolitan and cold-water species. He believes that the water temperature is the most effective of the various environmental factors determining the distribution of Recent Foraminifera. I disagree that the brackish-water arenaceous Foraminifera are cold-water species and that their distributions are restricted chiefly by temperature. It seems to me that HADA's idea is derived from the fact that brackish waters of very shallow lagoons and lakes in Japan (the depths from which HADA's samples were taken are mostly less than a few meters, and some from about $10 \mathrm{~m}$ ) are cooled during the winter and from the additional fact that many arenaceous Foraminifera are deep-sea inhabitants. If temperature is the limiting factor for the Trochammina Assemblage, why does this assemblage show the peculiar pattern that it does off the River Shinano and Santa Monica Bay regions? As above mentioned, there is no transitional zone between the fresh water of the Shinano and the underlying sea water. Therefore, the characteristics of the fresh water itself (temperature, salinity, etc.) have no influence on the benthonic Foraminifera. On the contrary, the detrital sediments and organic fragments carried by the River Shinano and deposited on the sea floor may influence on the benthonic Foraminifera distribution. When washing the present samples through a sieve (having openings of about 62 microns), I found a great deal of organic material. Generally organic material is considered to be an important food source of 
Foraminifera. Particularly, Trochammina pacifica off Santa Monica and Trochammina inflata in many places are abundant around the sewage outfall, in coastal lagoons or bays and in marine marshes. In the area off the River Shinano there is no quantitative study of organic material contained in the sediments. How ever, it seems to me that the organic content is as high in the Trochammina Assemblage zone as in the other assemblage zones. Also, the distribution of the Trochammina Assemblage is not related to the grain size distribution (compare Figure 3 with Figures 5 or 14).

The fact that the lower boundary of the Ammonia Assemblage is about $10 \mathrm{~m}$ and that the assemblage is confined to the area of sand distribution suggests that the $10 \mathrm{~m}$ boundary may represent the base of strong turbulence caused by wave action.

\section{Conclusion}

The distributions of species, assemblages and populations of Foraminifera are affected by the River Shinano. A good example is the distribution of Trochammina hadai. Along a traverse directly off the mouth of the Shinano, the Trochammina Assemblage is distributed from nearshore to $c a .6 \mathrm{~km}$ offshore (ca. $55 \mathrm{~m}$ deep). The $6 \mathrm{~km}$ wide Trochammina Assemblage zone becomes narrower in a northeasterly direction and finally, in a wedge-shape pattern, disappears at a point $c a .15 \mathrm{~km}$ northeast of the river mouth at a depth of $c a .25 \mathrm{~m}$. What factors of the river influence cause such a peculiar distribution of Foraminifera are not known. The detrital sediments and organic fragments transported by the River Shinano and deposited on the sea floor, salinity and temperature of the bottom water are not the most important factors, if considered seperately, but may be very important snythetically.

The Foraminifera and grain-size distributions are influenced by the River Shinano to a remarkable extent. These distributions are similar in general pattern but differ in some respects. This is because the grain-size distribution of sediments is influenced mostly by physical processes of river and sea waters while the distribution of organisms, including Foraminifera, is influenced by physical, chemical, biological, geological and geographical factors. Therefore, the interpretation of the distribution of organisms is not easy but, when interpreted correctly, will give a better understanding of the environmental conditions of sediments than does the distribution of grain size. The significance of this cannot be overemphasized. Foraminifera assemblages in Recent marine sediments are very useful in interpreting fossil assemblages, and, thus, the depositional environment of sedimentary rocks (Some fossil Foraminifera assemblages found in the Tertiary formations of the Niigata, Yamagata and Akita oil fields are very similar to the Recent Foraminifera assemblages off the River Shinana). It is to be regretted that there is a tendency among geologists to rely only on the phy- 
sical and/or chemical characteristics of sediments or sedimentary rocks. This appears to me be an erroneous and shortsighted view.

\section{Systematic Descriptions}

Four new species, two new subspecies and a species similar to a known species are figured in this area. In addition, Haplophragmoides bradyi hokkaidoensis, n. subsp., though not found in this area, is described here for the convenience of comparison with $H$. bradyi niigataensis, n. subsp. Brief taxonomic notes on some species are also mentioned. All specimens figured in this paper are deposited tentatively at my laboratory, Petroleum Engineering Institute, University of Tokyo. Some of the paratypes are deposited at the United States National Museum, Washington 25, D. C.

Haplophragmoides bradyi hokkaidoensis UcHIO, n. subsp.

(Plate XVIII, Figures 7a, b)

Test free, small, compressed, nearly circular and lobulated in side view, planispiral, incompletely involute; periphery broadly rounded in edge view; chambers numerous, inflated, 6-6 6 , usually 6 chambers in the last whorl, those of the previous whorl slightly exposed in the depressed umbilical region; sutures distinct, depressed, straight, radiate; wall finely arenaceous with much cement, surface smooth and shining as polished, color reddish brown to yellowish brown; aperture interio-marginal, forming a crescentic slit at the base of the apertural face of the last chamber, with an upper lip.

Holotype (Uchio Collection No. TU-1001) from Station 10, off Noboribetsu, Hokkaido, Japan (N. Lat. $42^{\circ} 25^{\prime} 37^{\prime \prime}$, E. Long. $141^{\circ} 18^{\prime} 15^{\prime \prime}$; depth $80 \mathrm{~m}$ ). Length $c a$. $0.28 \mathrm{~mm}$, width ca. $0.14 \mathrm{~mm}$.

Remarks...This new subspecies occurs at Station $6(56 \mathrm{~m}), 3(59 \mathrm{~m})$ and 10 $(80 \mathrm{~m}$ ) in very low frequency (less than 1\%) off Noboribetsu, Hokkaido (Uchio, 1959 , p. 300 , listed as Haplophragmoides bradyi in Table 2).

Comparison...When I described Haplophragmoides neobradyi UchIo (1960, p. 51), I discussed the characteristics of $H$. bradyi (RoBERTSON) in detail based on the original description and five topotypic specimens. $H$. bradyi is a nonvariable form, hence even a minor change in morphology becomes important in separating species or subspecies in $H$. bradyi group. H. bradyi hokkaidoensis differs from $H$. bradyi in having a less evolute, less deeply umbilicated test and fewer number of chambers in the last whorl. H. bradyi hokkaidoensis differs from $H$. neobradyi in having more chambers ( $H$. neobradyi has $4-5$ chambers) in the last whorl, and a slightly more inflated and more stout test. 
Haplophragmoides bradyi niigataensis UcHI, n. subsp.

(Plate XVIII, Figures 6a, b)

Test free, small, subglobose, nearly completely involute in the young stages, slightly evolute and slightly umbilicate in the adult stages; periphery nearly circular and slightly lobulated in side view, very broadly rounded in edge view; five chambers in the last whorl, each gradually or slightly rapidly increasing in size as added; sutures distinct, depressed, straight or very slightly curved; wall finely arenaceous with much cement, surface smooth and shining as polished, color reddish to yellowish brown; aperture interio-marginal, forming a crescentic slit at the base of the apertural face of the last chamber, with an upper lip.

Holotype (Uсніо Collection No. TU-1003) from Station 76, off the River Shinano, Niigata-ken, Japan (N. Lat. $18^{\circ} 3^{\prime} 3.2^{\prime \prime}$, E. Long. $138^{\circ} 9^{\prime 28.3^{\prime \prime}}$; depth $65 \mathrm{~m}$ ). Length $c a .0 .33 \mathrm{~mm}$, width $c a .0 .27 \mathrm{~mm}$.

Comparison...Haplophragmoides bradyi niigataensis differs from $H$. bradyi in having a much more inflated and less evolute test $(H$. bradyi always shows a part of the previous two whorls and hence is more deeply umbilicate). H.bradyi niigataensis differs from $H$. neobradyi in having a much more inflated test. $H$. bradyi niigataensis differs from $H$. bradyi hokkaidoensis in having a slightly less evolute and more inflated test, and fewer number of chambers in the last whorl. The following table shows the characteristics of the various forms.

\begin{tabular}{|c|c|c|c|c|}
\hline & bradyi & neobradyi & hokkaidoensis & niigataensis \\
\hline $\begin{array}{l}\text { no. of chambers in the } \\
\text { last whorl }\end{array}$ & $5-5 \frac{1}{2}$ & $\begin{array}{c}5 \\
\left.\text { (rarely } 4 \frac{1}{2}\right)\end{array}$ & $\begin{array}{c}6 \\
\text { (sometimes } 6 \frac{1}{2} \text { ) }\end{array}$ & 5 \\
\hline $\begin{array}{l}\text { no. of previous whorl } \\
\text { partly visible }\end{array}$ & 2 & 1 & 1 & 1 \\
\hline umbilicus & $\begin{array}{c}\text { deeply } \\
\text { umbilicate }\end{array}$ & umbilicate & umbilicate & umbilicate \\
\hline test & $\begin{array}{c}\text { much } \\
\text { compressed }\end{array}$ & $\begin{array}{c}\text { much } \\
\text { compressed }\end{array}$ & compressed & subglobose \\
\hline
\end{tabular}

Textularia satoi UcHIO, n. sp.

(Plate XVIII, Figures $1 \mathrm{a}, \mathrm{b} ; 2 \mathrm{a}, \mathrm{b}$ )

Test free, small and fragile for the genus, tapering, broadest near the apertural end, elongate, about three times as long as broad, very strongly compressed, slightly inflated in the middle of the flattened sides, rarely slightly twisted; periphery somewhat acute, lobulate; chambers numerous, early ones close coiled at least in the microspheric form, later ones biserial, about twice as broad as high; sutures distinct, depressed, straight, oblique; wall arenaceous, composed mostly of fine sand grains and some relatively large ones; aparture a narrow slit 
at the base of the apartural face of the last chamber.

Holotype (UchIo Collection No. TU-1006) from Station 44, off the River Shinano, Niigata-ken, Japan (N. Lat. $38^{\circ} 4^{\prime} 43.8^{\prime \prime}$, E. Long. $139^{\circ} 12^{\prime} 55.8^{\prime \prime}$; depth $60 \mathrm{~m}$ ). Length ca. $0.27 \mathrm{~mm}$; width ca. $0.12 \mathrm{~mm}$.

Paratype (Uchio Collection No. TU-1006) from the same station as the holotype. Length $c a .0 .27 \mathrm{~mm}$; width $c a .0 .11 \mathrm{~mm}$.

Comparison....This new species can be easily distinguished from other species of the genus in having a small fragile and very strongly compressed test. Textularia antarctica (WIESNER) (1931, p. 99, pl. 21, figs. 257, 258; pl. 23, fig. c) is close to this new species, but differs in having more inflated test, less elongate chamber, and aperture, a narrow slit, being parallel to the flattened side of the test instead of at right angles to them as in $T$. satoi.

\section{Elphidium clavatum CUSHMAN}

Elphidium incertum (WIlliamson) var. clavatum Cushman, 1930, U. S. Nat. Mus., Bull. 104, pt. 7, p. 20, pl. 7, figs. 10a, b.-Cushman, 1939, U. S. Geol. Survey, Prof. Paper 191, p. 57, pl. 16 , figs. 1,2 .

Elphidium clavatum Cushman, Loeblich \& TAPPAN, 1953, Smithsonian Misc. Coll., vol. 121, no. 7 , p. 98 , pl. 19 , figs. 8-10.

Elphidium decipiens HADA (not CosTA), 1931, Sci. Rept. Tohoku Imp. Univ., ser. 4 (Biology), vol. 6 , no. 1, p. 126 , textfig. 83 .

Elphidium hughesi foraminosum, AsANo, 1950, Illustrated catalogue of Japanese Tertiary smaller Foraminifera, pt. 1, p. 8, figs. $46,47$.

I can not compare my material with topotypic material of Elphidum clavatum. Cushman (1939) mentions the presence of this species in Recent sediments in Kiollie Fjord, Norway. I have a part of the Cushman's material in Killie Fjord (which Cushman gave it to Dr. Yoshiaki Ozawa), and find many specimens of this species. My specimens off the River Shinano and off Noboribetsu are identical to the Kiollie specimens as well as to the Arctic specimens figured by LoEblich \& TAPPAN (1953). I have found many specimens of this species in a siltstone of the Wakimoto formation (Pliocene) at Oibanazaki, Wakimoto-mura, Minamiakita-gun, Akita-ken, Japan, which must be the same species as the one identified as E. hughesi foraminosum Cushman by Asano (1950). Asano's figures show that the sutures are straight (which means the specimen is identical to $E$. foraminosum (CUSHMAN), but his description mentions the sutures are slightly curved toward periphery. My many specimens at Oibanazaki show curved sutures and should be identified to E. clavatum. E. foraminosum may be within the range of variation of $E$. clavatum. 
Lagena pliocenica tokiokai UcHo, n. subsp.

(Plate XVIII, Figures 10a, b)

Test free, flask-shaped, the greatest width near the base which is truncated, with a long cylindrical neck, lower half of the test with many short raised longitudinal costae ending sometimes in acute projections near the base of the test; aperture at the end of an elongate, tapering neck ornamented with longitudinal costae, occasionally tending to become slightly spiral.

Holotype (Uchio Collection No. 1007) from Station 24, off the River Shinano, Niigata-ken, Japan (N. Lat. $38^{\circ} 4^{\prime} 50.3^{\prime \prime}$, E. Long. $139^{\circ} 17^{\prime} 33.1^{\prime \prime}$; depth $39 \mathrm{~m}$ ). Length ca. $0.58 \mathrm{~mm}$, width ca. $0.28 \mathrm{~mm}$.

Comparison...This new subspecies differs from $L$. pliocenica in that the main portion of the test of $L$. pliocenica is roughly triangular or semi-circular in side view and thus the greatest width near the base, while that of $L$. pliocenica tokiokai is somewhat pyriform, and widest about the middle of it.

\section{Trochammina hadai UcHIo, n. sp.}

(Plate XVIII, Figures 9a-c)

Test free, trochoid, finely arenaceous, dorsal side convex, ventral one usually flattened, umbilical area rather flat but deeply umbilicate in well preserved specimens, usually covered by fine particles, consisting of from 3 to 4 whorls, all visible from the dorsal side, only the last one from the ventral side; chambers inflated, somewhat subglobose, usually 5 , occasionally 4 chambers in the last whorl, usually gradually, sometimes rapidly increasing in size as added; sutures slightly curved dorsally, more depressed and nearly radial ventrally; aperture an arched slit at the base of the apertural face of the last chamber; wall of sand grains and a variable amount of cement, outer surface fairly even, color reddish brown to yellowish brown.

Holotype (Uchio Collection No. TU-1009) from Station 70, off the River Shinano, Niigata-ken, Japan (N. Lat. $37^{\circ} 59^{\prime} 45.4^{\prime \prime}$, E. Long. $139^{\circ} 11^{\prime} 53.8^{\prime \prime}$; depth $45 \mathrm{~m}$ ). Length ca. $0.52 \mathrm{~mm}$, width $c a .0 .48 \mathrm{~mm}$.

Remarks...This new species seems to be widely distributed in Japanese brackish waters, and is reported as Trochammina (or rarely Ammoglobigerina) globigeriniformis (PARKER \& Jones) (HADA, 1931, 1936, 1939, 1957; MARUHASI, 1948, 1951; Takayanagi, 1955) or T. cf. globigeriniformis (Uchio, 1962 A, B). However, true $T$. globigeriniformis is a very common and widely distributed species in deep, cold waters (Cushman, 1910, p. $124 ; 1920$, p. 78). I have many specimens of true T. globigeriniformis from San Diego Trough, California (Uchio, 1960, pl. 5, figs. 21,22 ). T. hadai differs from $T$. globigeriniformis in having a 
smaller and somewhat less stout test, less deeply depressed sutures, less inflated chambers, less lobulated periphery, and usually fewer number of chambers in the last whorl (though many specimens of $T$. hadai at Tanabe Bay have 4 chambers in the last whorl). Thus, the two species are distinct from each other in morphological as well as ecological characters. T. hadai also differs from $T$. pacifica Cushman in having much more inflated chambers. The tribial name of this new species is dedicated to Mr. Yoshine HADA in recognition of his studies in the brackish-water Foraminifera in Japan.

\section{Trochammina sp. cf. T. pacifica CUSHMAN}

(Plate XVIII, Figures 8a-c)

Remarks...Trochammina pacifica Cushman was originally described from off Virago Sound, off British Columbia at depths of 8-15 fathoms (Cushman, 1925, p. 104). T. charlottensis Cushman was described at the same time from the same area. I (Uсніо, 1960, p. 58) mentioned the difficulty of separating $T$. pacifica from $T$. charlottensis. I have many specimens of $T$. pacifica from off the San Diego, California, area (Uchio, 1960, p. 59, pl. 3, figs. 26, 27), and have compared them with $T$. cf. pacifica off the River Shinano. It is found that the Japanese form is very close to the San Diego form, but has a more compressed and less deeply umbilicate test. Furthermore, each chamber of the San Diego form is more elongate than that of the Japanese form. As mentioned elsewhere in this paper, Zalesny's T. pacifica in Santa Monica Bay, California must be different from my $T$. cf. pacifica when considered from an ecological point of view. The Japanese form may be closer to $T$. charlottensis than to $T$. pacifica.

Hypotype (Uchio Collection No. TU-1011) from Station 70, off the River Shinano, Niigata-ken, Japan (N. Lat. $37^{\circ} 59^{\prime} 45.4^{\prime \prime}$, E. Long. $139^{\circ} 11^{\prime} 53.8^{\prime \prime}$; depth $24 \mathrm{~m}$ ). Length $c a .0 .48 \mathrm{~mm}$, width $c a .0 .39 \mathrm{~mm}$.

\section{Bolivina hadai UcHIo, n. sp.}

(Plate XVIII, Figures 3a, b; $4 \mathrm{a}, \mathrm{b}$ )

The free, somewhat compressed, slightly twisted, elongate, about three times as long as broad, broadest near the apertural end, tapering slightly toward the aboral end which always has a short spine; periphery lobulated in side view, rounded in edge view; chambers numerous, biserial, inflated, broader than high, increasing gradually in size as added except the last two which are relatively large; sutures distinct, slightly limbate, depressed except in early portions where they flush with surface, oblique, nearly straight; wall hyaline, somewhat coarsely perforate; aperture terminal, wide, elongate, curved, extending to the base of the 
inner margin of the last chamber.

Holotype (Uchio Collection No. TU-1012) from Station 104, off the River Shinano, Niigata-ken, Japan (N. Lat. $38^{\circ} 9^{\prime} 53.5^{\prime \prime}$, E. Long. $139^{\circ} 20^{\prime} 15.5^{\prime \prime}$; depth $43 \mathrm{~m}$ ). Length $c a .0 .53 \mathrm{~mm}$, width $c a .0 .19 \mathrm{~mm}$.

Paratype (Uchio Collection No. TU-1013) from Station 112, off the River Shinana, Niigata-ken, Japan (N. Lat. $38^{\circ} 11^{\prime} 58.4^{\prime \prime}$, E. Long. 139'20'22.8' ; depth $48 \mathrm{~m}$ ). Length $c a .0 .50 \mathrm{~mm}$, width $c a .0 .19 \mathrm{~mm}$.

Comparison...This new species is similar to Bolivina seminuda HADA (not Cushman) (HADA, 1931, p. 132, textfig. 89) in its general shape, apertural character and somewhat coarsely perforated wall, but differs in its slightly twisted test, much wider aperture, a short spine at the aboral end of the test, and its wall being somewhat coarsely perforated all over the surface in stead of being so only on the proximal area of each chamber as in $B$. seminuda HadA. This new species is also similar to $B$. tosaensis Asano (1958, p. 23, pl. 4, figs. 3, 4) but differs in its much larger aperture, oblique and slightly limbate sutures and less coarsely perforated wall surface.

\section{Bolivina tokiokai UcHIO, n. sp. \\ (Plate XVIII, Figures $5 \mathrm{a}, \mathrm{b}$ )}

Test free, slightly compressed, elongate, about $2 \frac{1}{2}$ times as long as broad, periphery broadly rounded, tapering gradually, greatest breadth formed by the last two pairs of chambers, initial end bluntly pointed, without a spine, early portions slightly twisted; chambers numerous, biserial throughout, distinct except in early portions, somewhat inflated, broader than high, increasing gradually in size as added; sutures distinctly depressed, straight, horizontal except in early portions; wall coarsely pitted or finely reticulated except on the surface of the last chamber which is less so ; aperture broadly elliptical, narrow at the base.

Holotype (Uchio Collection No. TU-1014) from Station 60, off the River

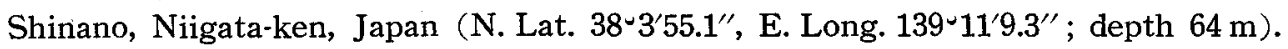
Length $c a .0 .46 \mathrm{~mm}$, width $c a .0 .21 \mathrm{~mm}$.

Comparison...This new species is similar to Bolivina tosaensis Asano (1958, p. 23, pl. 4, figs. 3,4 ), but digers from it in having more inflated test which has no spine at the initial end, aperture without a lip, and test tapering more gradually.

\section{REFERENCES}

AkAGAwA, M. 1952. Results of the oceanographic observations in the northern Japan Sea during August 1-19, 1951: Kaiyo Sokuho, No. 38, Hakodate Marine Meteorological Observatory. ASANo, K., 1958. The Foraminifera from the adjacent seas of Japan, collected by the S. S. Soyomaru, 1922-1930, Pt. 4-Buliminidae. Sci. Rept. Tohoku Univ., Sendai, Japan, second ser. (Geology), vol. 29 , pp. 1-41, pls. 1-7. 
Cushman, J. A. 1910. A monograph of the Foraminifera of the North Pacific Ocean, Pt. 1. Astrorhizidae and Lituolidae. U. S. Nat. Mus., Bull. 71, pp. 1-134.

1920. The Foraminifera of the Atlantic Ocean, Pt. 2. Lituolidae. U. S. Nat. Mus., Bull. 104, pp. 1-111, pls. 1-18.

1925. Recent Foraminifera from British Columbia. Contr. Cushman Lab. Foram. Res., vol. 1, pt. 2 , pp. $38-45$, pls. 6,7 .

1930. The Foraminifera of the Atlantic Ocean, Pt. 7. Nonionidae, Camerinidae,

Peneroplidae and Alveolinellidae. U. S. Nat. Mus., Bull. 104, pp. 1-79, pls. 1-18.

1939. A monograph of the Foraminiferal Family Nonionidae. U. S. Geol.

Survey, Prof. Paper 191, pp. 1-100, pls. 1-20.

FUJII, M. \& IGARASHI, M. 1952. Results of the simultaneous oceanographic observations in the Tsushima Current region during the summer of 1951. Spec. issue, Suiro Jiho, 9th Branch of the Japanese Maritime Safety Agency.

HADA, Y. 1931. Report of the biological survey of Mutsu Bay. No. 19. Notes on the Recent Foraminifera from Mutsu Bay. Sci. Rept. Tohoku Imp. Univ., 4 ser. (Biology), vol. 6, no. 1, pp. $45-148$.

1936. Studies on the Foraminifera of brackish waters. I. Hijirippu and Mochirippu

Lakes. Zool. Mag. (Japan), vol. 48, nos. 8-10, pp. 847-860 (in Japanese with English abstract.)

1939. Studies on the Foraminifera of brackish waters. IV. The Foraminifera of Naka-

noumi. Zool. Mag. (Japan), vol. 51, no. 3, pp. 135-140 (in Japanese with English abstract).

1957. Biology of the arenaceous Foraminifera. Jour. Sci. Suzugamine College, Hiroshima, vol. 3 , pp. 31-50.

Hydrographic Office of Japan. 1955. Records of oceanographic and meteorological observations at stations. pp. 24-164.

Japan Sea Regional Fisheries Research Laboratory. 1953. Results of the simultaneous oceanographic observations in the Tsushima Current region during the summer of 1952 .

LoEblich, A. R. \& Tappan, H. 1953. Studies of Arctic Foraminifera. Smithsonian Misc. Coll., vol. 121 , no. 7 , pp. $1-150$, pls. $1-24$.

MARUHAsi, M. 1948. Foraminifera fauna of the Tokyo Bay. Misc. Rept. Research Institute for Natural Resources, no. 12, pp. 37-41 (in Japanese with English abstract).

NAGAHAMA (formerly MARuHasi) M. 1951. Studies on the foraminiferal fauna of small or almost enclosed bays in Japan. ibid., nos. 19-21, pp. 142-148 (in Japanese with English abstract).

Niigata Prefectural Fisheries Experimental Station. 1954. General reports of the Tsushima Current survey, no. 2. pp. 1-99 (in Japanese).

Sato, T. 1960. On the bottom sediments off the coast of Kitakanbara, Niigata Prefecture, Japan. Jour. Geol. Soc. Japan, vol. 66, no. 782, pp. 710-716 (in Japanese with English abstract).

Shimomura, T. \& MiyatA, K. 1957. The oceanographic conditions of the Japan Sea and its water systems, laying stress on the summer of 1955. Japan Sea Regional Fisheries Research Laboratory, Fisheries Agency, Bull. no. 6, pp. 23-119 (in Japanese with English abstract).

TAKAYANAGI, Y. 1955. Recent Foraminifera from Matsukawa-ura and its vicinity. Contr. Inst. Geol. Paleont., Tohoku Univ., No. 45, pp. 18-52, pls. 1, 2.

UchIo, T. 1959. Ecology of shallow-water Foraminifera off the coast of Noboribetsu, southwestern Hakkaido, Japan. Publ. Seto Mar. Biol. Lab., vol. 7, no. 3, pp. 295-302.

1960. Ecology of living benthonic Foraminifera from the San Diego, California, area.

Cushman Found. Foram. Res., Spec. Publ. No. 5, pp. 1-72, pls. 1-10, textfigs. 1-18, tables 1-9. 1960. Shallow water Foraminifera assemblages off the coast of Kitakanbara-gun,

Niigata Prefecture. Jour. Geol. Soc. Japan, vol. 66, p. 453 (abstract).

1962A. Recent Foraminifera thanatocoenoses of beach and nearshore sediments along

the coast of Wakayama-ken, Japan. Publ. Seto Mar. Biol. Lab., vol. 10, no. 1, pp. 133-144.

1962B. Influence of the River Shinano on Foraminifera and sediment grain size di- 
stributions. In; "SHEPARD Commemorative Volume: Papers in Marine Geology", MacMillan Publ. Co. New York (in press).

WIESNer, H. 1931. Die Foraminiferen der Deutschen Südpolar-Expedition 1901-1903. Deutsche Südpolar-Expedition, vol. 20, Zoologie, pp. 53-165, pls. 1-24.

ZALESNY, E. R. 1959. Foraminifera ecology of Santa Monica Bay, California. Micropaleontology, vol. 5 , no. 1 , pp. 101-126. 


\section{EXPLANATION OF PLATE XVIII}

Figs. $1 \mathrm{a}, \mathrm{b} ; 2 \mathrm{a}$, b. Textularia satoi Uchіо, n. sp.

Figs. 1 a, b: Holotype (TU-1005), $\times 142$

Figs. 2a, b: Paratype (TU-1006), $\times 142$

Figs. 3a, b; 4 a. b. Bolivina hadai Uchı, n. sp.

Figs. 3a, b: Paratype (TU-1013), $\times 62$

Figs. $4 \mathrm{a}, \mathrm{b}$ : Holotype (TU-1012), $\times 62$

Figs. $5 \mathrm{a}, \mathrm{b}$.

Bolivina tokiokai Uсніо, n. sp.

Holotype (TU-1014), $\times 78$

Figs. 6a, b.

Haplophragmoides bradyi niigataensis Uсніо, n. subsp.

Holotype (TU-1003), $\times 93$

Figs. 7 a, b.

Haplophragmoides bradyi hokkaidoensis UcHIo, n. subsp.

Holotype (TU-1001), $\times 79$

Figs. 8a-c.

Trochammina sp. cf. T. pacifica CushmaN

Hypotype (TU-1011), $\times 60$

Figs. $9 a-c$.

Trochammina hadai $\mathrm{UCHIO}$, n. sp.

Holotype (TU-1009), $\times 58$

Figs. 10a, b. Lagena pliocenica tokiokai Uchio, n. subsp.

Holotype (TU-1007), $\times 64$ 


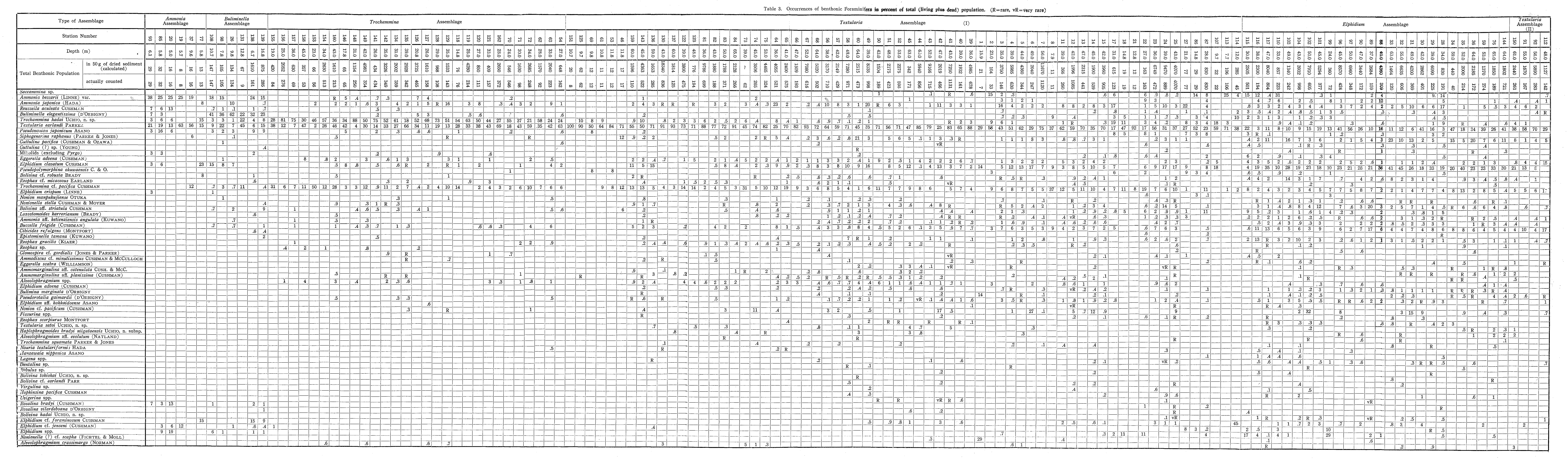


Publ. Seto Mar. Biol. Lab., X, 2 (1962)

PLATE XVIII
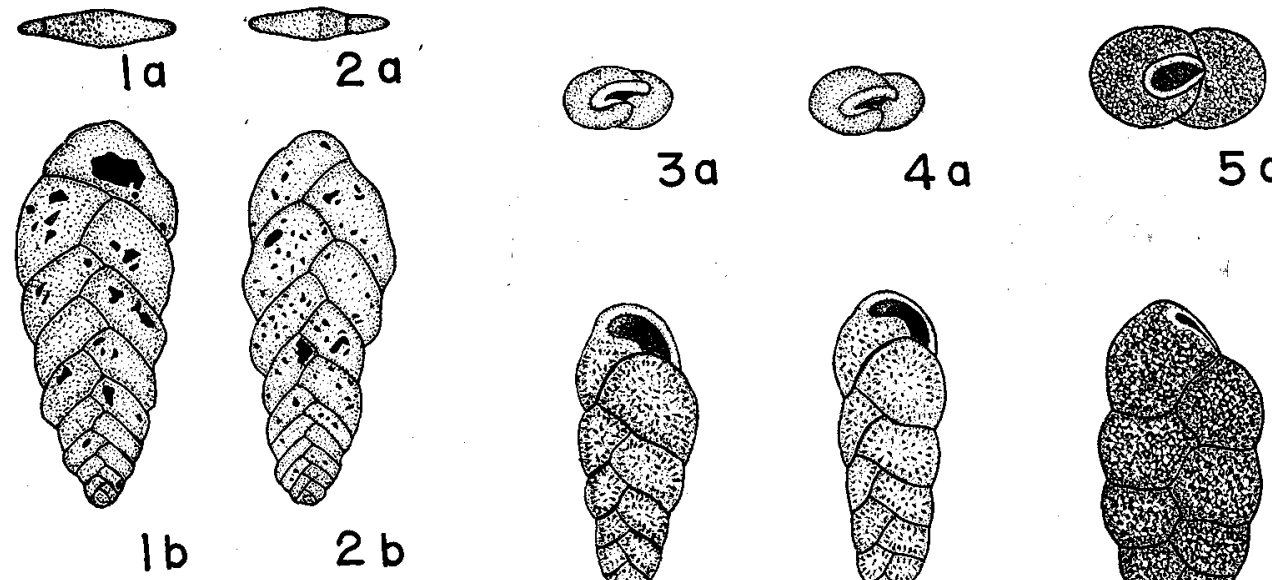

$3 a$

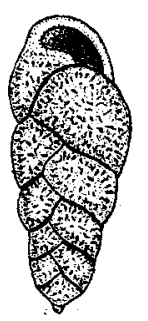

$3 b$

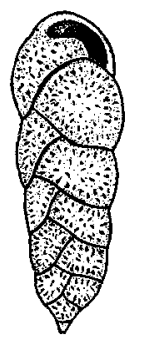

$4 b$

$5 a$
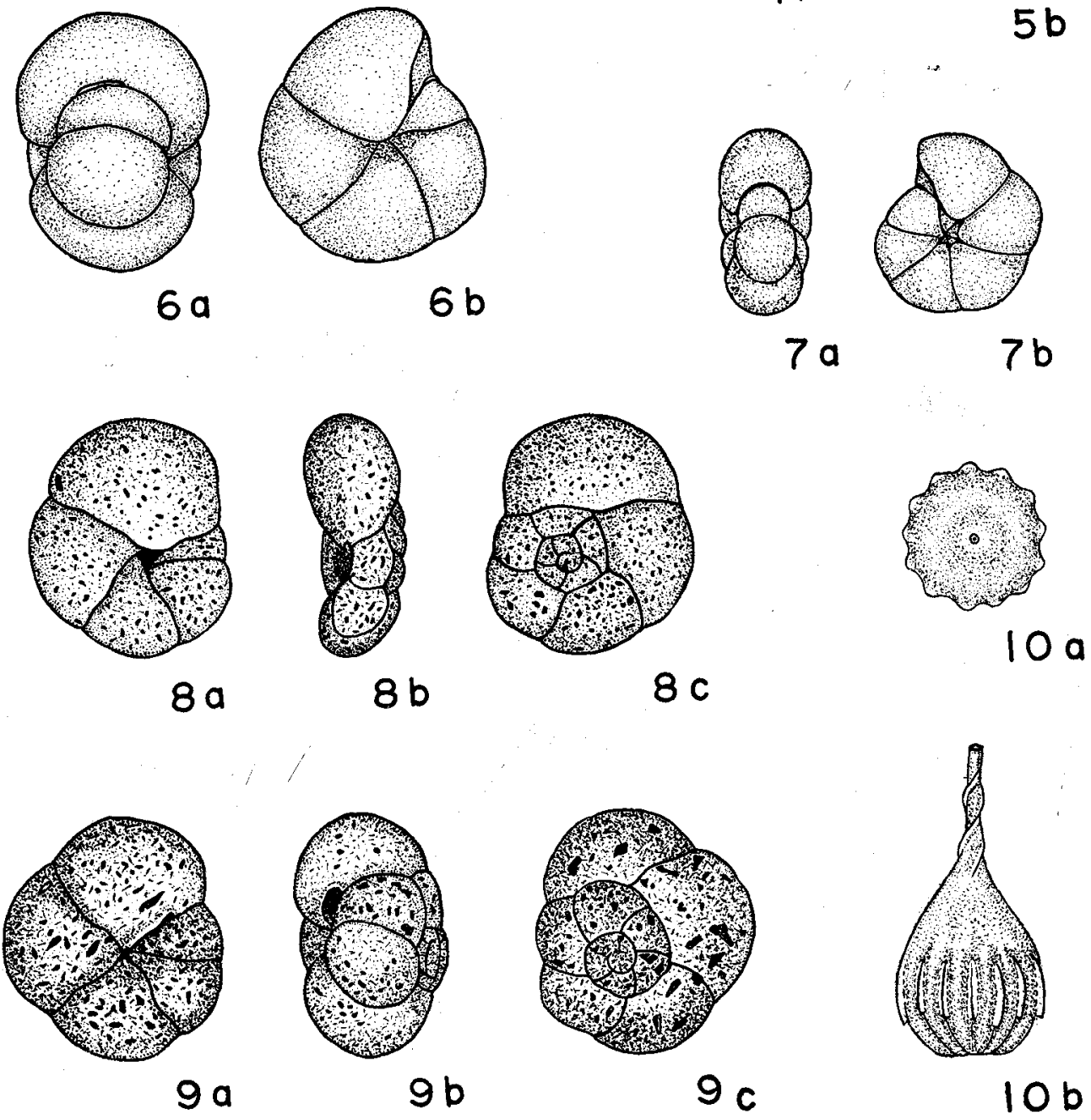

T. UChio: Influence of River Shinano on Foraminifera and Sediment 